\title{
Lung toxicities of core-shell nanoparticles composed of carbon, cobalt, and silica
}

This article was published in the following Dove Press journal:

International Journal of Nanomedicine

20 March 2013

Number of times this article has been viewed

\author{
Mohammed T Al Samri ${ }^{1, *}$ \\ Rafael Silva ${ }^{2, *}$ \\ Saeeda Almarzooqi ${ }^{3}$ \\ Alia Albawardi ${ }^{3}$ \\ Aws Rashad Diab Othman' \\ Ruqayya SMS AI Hanjeri' \\ Shaikha KM AI Dawaar' \\ Saeed Tariq ${ }^{4}$ \\ Abdul-Kader Souid' \\ Tewodros Asefa ${ }^{2,5}$ \\ 'Department of Pediatrics, United \\ Arab Emirates University, Abu Dhabi, \\ United Arab Emirates; ${ }^{2}$ Department \\ of Chemistry and Chemical Biology, \\ Rutgers, The State University \\ of New Jersey, Piscataway, NJ, \\ USA; ${ }^{3}$ Department of Pathology, \\ ${ }^{4}$ Department of Anatomy, United \\ Arab Emirates University, Abu Dhabi, \\ United Arab Emirates; ${ }^{5}$ Department \\ of Chemical Engineering and \\ Biochemical Engineering, Rutgers, \\ The State University of New Jersey, \\ Piscataway, NJ, USA \\ *These authors contributed equally \\ to this work
}

Correspondence: Tewodros Asefa Department of Chemistry and Chemical Biology and Department of Chemical Engineering and Biochemical Engineering Rutgers, The State University of New Jersey, 610 Taylor Road, Piscataway, NJ 08854, USA

Tel +l 8484452970

$\mathrm{Fax}+\mathrm{I} 7324455312$

Email tasefa@rci.rutgers.edu

\begin{abstract}
We present here comparative assessments of murine lung toxicity (biocompatibility) after in vitro and in vivo exposures to carbon $\left(\mathrm{C}-\mathrm{SiO}_{2}\right.$-etched $)$, carbon-silica $\left(\mathrm{C}-\mathrm{SiO}_{2}\right)$, carbon-cobalt-silica $\left(\mathrm{C}-\mathrm{Co}-\mathrm{SiO}_{2}\right)$, and carbon-cobalt oxide-silica $\left(\mathrm{C}-\mathrm{Co}_{3} \mathrm{O}_{4}-\mathrm{SiO}_{2}\right)$ nanoparticles. These nanoparticles have potential applications in clinical medicine and bioimaging, and thus their possible adverse events require thorough investigation. The primary aim of this work was to explore whether the nanoparticles are biocompatible with pneumatocyte bioenergetics (cellular respiration and adenosine triphosphate content). Other objectives included assessments of caspase activity, lung structure, and cellular organelles. Pneumatocyte bioenergetics of murine lung remained preserved after treatment with $\mathrm{C}-\mathrm{SiO}_{2}$-etched or $\mathrm{C}-\mathrm{SiO}_{2}$ nanoparticles. $\mathrm{C}-\mathrm{SiO}_{2}-$ etched nanoparticles, however, increased caspase activity and altered lung structure more than $\mathrm{C}-\mathrm{SiO}_{2}$ did. Consistent with the known mitochondrial toxicity of cobalt, both $\mathrm{C}-\mathrm{Co}-\mathrm{SiO}_{2}$ and $\mathrm{C}-\mathrm{Co}_{3} \mathrm{O}_{4}-\mathrm{SiO}_{2}$ impaired lung tissue bioenergetics. $\mathrm{C}-\mathrm{Co}-\mathrm{SiO}_{2}$, however, increased caspase activity and altered lung structure more than $\mathrm{C}-\mathrm{Co}_{3} \mathrm{O}_{4}-\mathrm{SiO}_{2}$. The results indicate that silica shell is essential for biocompatibility. Furthermore, cobalt oxide is the preferred phase over the zerovalent $\mathrm{Co}(0)$ phase to impart biocompatibility to cobalt-based nanoparticles.
\end{abstract}

Keywords: carbon nanoparticles, cobalt nanoparticles, silica nanoparticles, cobalt oxide nanoparticles, biocompatibility, nanotoxicology

\section{Introduction}

The potential adverse effects of nano- and micromaterials on human health are of great concern and contemporary interest. The burgeoning need for being vigilant with nanomaterials has increased in the last few decades, as many of them have been considered for a diverse range of applications. These functions include drug delivery, biomedical imaging, catalysis, and sensors. Some nanomaterials have actually obtained commercial use already, a trend that is likely to continue for many more nanomaterials in areas such as renewable energy, environmental remediation, and nanomedicine. The potential toxicities of many nanomaterials, however, remain not fully addressed.

Owing to their structural, chemical, and physical properties, carbon-based nanomaterials have received special interest in biomedical applications..$^{1-3}$ Furthermore, they are good light absorbers as a result of their extensive conjugated $\mathrm{sp}^{2}-\mathrm{sp}^{2}$ linkages and $\pi$-orbital electron delocalization. ${ }^{4}$ Consequently, carbon nanomaterials can serve as heating agents for treatment of cancer via photothermal heating of tumor tissue using near-infrared light. ${ }^{5}$ In addition, they exhibit high mechanical stiffness and chemical stability due to their carbon atoms' unique geometric arrangements. This property, along with their high electrical conductivity, makes carbon nanomaterials important 
building blocks for development of efficient nanosensors for early detection of various human diseases.

Similarly, silica represents another class of nanomaterials that possesses interesting properties suitable for biomedical, biosensing, and drug-delivery applications. ${ }^{6}$ Furthermore, when used as a nanoshell, silica can serve as a protecting layer, making nanomaterials biologically compatible and water-dispersible. For example, silica was successfully utilized as a shell to coat Fe-based magnetic nanoparticles and reduced direct toxicities associated with the metal. ${ }^{7}$ Such magnetic metal nanoparticles - typically composed of iron and cobalt - are more suitable for bioimaging. ${ }^{8}$ Even though cobalt is reported to have mitochondrial toxicity, ${ }^{9}$ the use of cobalt in nanomedicine is desired, because cobalt nanoparticles boost sensitivity and edge detection on magnetic resonance imaging due to their enhanced magnetic properties. ${ }^{10,11}$

The use of silica as nanoshell on other nanomaterials is also appealing because the silica shell makes the chemical modification of nanomaterials (eg, with cell-targeting groups) possible due to the reactivity of silanol groups on the silica surfaces. ${ }^{12,13}$ In addition, silica-based materials and nanoshells are easy to synthesize and remain stable under various biological conditions. These features make silica nanostructures versatile systems for immobilization of diverse types of bioactive molecules, such as celltargeting groups and antibodies for biological and medical applications. ${ }^{12-14}$

We recently reported an in vitro method for assessing murine tissue (lung, liver, kidney, spleen, and pancreas) and human cell (lymphocyte and fibroblast) bioenergetics and other biomarkers. ${ }^{15-18}$ Using the method, for instance, lung tissue was maintained viable in vitro for several hours, allowing its accurate analyses. The same method was employed to show biocompatibility of mesoporous silica nanoparticles in various murine tissues. ${ }^{19}$

It is known that monitoring mitochondrial function (e.g., measuring oxygen consumption and ATP content) can also serve as a highly sensitive method for assessing apoptosis - the mechanism responsible for initiation and execution of cellular response to injury. The "initiation" phase requires leakage of cytochrome $\mathrm{c}$ from the mitochondrial intermembrane to the cytosol. In the cytosol, cytochrome c binds to the apoptotic protease activating factor-1, triggering the caspase cascade (a series of cysteine, aspartate-specific proteases). Caspase activation executes mitochondrial dysfunction and DNA fragmentation. The mitochondrial perturbation involves two processes: 1) the opening up of permeability transition pores, accelerating oxidations in the mitochondrial respiratory chain, and 2) the collapse of the electrochemical potential $\Delta \psi \cdot{ }^{20}$ Cytochrome c- and apoptosome-independent pathways for caspase activation are also reported. ${ }^{21}$ Thus, induction and execution of apoptosis are both linked to the mitochondria. Therefore, monitoring mitochondrial function (eg, measuring $\mathrm{O}_{2}$ consumption and adenosine triphosphate [ATP] content) is highly sensitive in assessing apoptosis. Synthetic cell-permeable substrates, such as $\mathrm{N}$-acetylDEVD-7-amino-4-methyl coumarin (Ac-DEVD-AMC), have been used to investigate caspase activities. For example, cleavage of Ac-DEVD-AMC by specific caspases releases the fluorogenic AMC; the latter can be separated on high-performance liquid chromatography (HPLC) and detected by fluorescence with great sensitivity. ${ }^{22}$ We here employed the biomarkers generated by murine lung upon treatment with carbon $\left(\mathrm{C}-\mathrm{SiO}_{2}\right.$-etched), carbon-silica $\left(\mathrm{C}-\mathrm{SiO}_{2}\right)$, carbon-cobalt-silica $\left(\mathrm{C}-\mathrm{Co}-\mathrm{SiO}_{2}\right)$, and carbon-cobalt oxide-silica $\left(\mathrm{C}-\mathrm{Co}_{3} \mathrm{O}_{4}-\mathrm{SiO}_{2}\right)$ nanoparticles to assess in vitro and in vivo biocompatibilities of these nanomaterials.

\section{Materials and methods \\ Reagents}

Pd(II) complex of meso-tetra-(4-sulfonatophenyl)tetrabenzoporphyrin (Pd phosphor) was purchased from Porphyrin Products (Logan, UT, USA). Ac-DEVD-AMC (MW 729.6) was obtained from Axxora (San Diego, CA, USA). A lyophilized powder of caspase inhibitor I (zVAD-fmk, MW $\approx 467.5$ ) was purchased from Calbiochem (La Jolla, CA, USA). Glucose (anhydrous), bovine serum albumin (free of endotoxins and fatty acids), and the remaining reagents were all received from Sigma-Aldrich (St Louis, MO, USA).

The caspase-3 substrate Ac-DEVD-AMC was dissolved in dimethyl sulfoxide at $6.85 \mathrm{mM}$ and stored at $-20^{\circ} \mathrm{C}$ in small aliquots. The zVAD-fmk solution $(2.14 \mathrm{mM})$ was made by dissolving $1.0 \mathrm{mg}$ of zVAD-fmk in $1.0 \mathrm{~mL}$ of dimethyl sulfoxide and stored at $-20^{\circ} \mathrm{C}$. A freshly prepared KrebsHenseleit (KH) buffer (115 mM NaCl, $25 \mathrm{mM} \mathrm{NaHCO}_{3}$, $1.23 \mathrm{mM} \mathrm{NaH}_{2} \mathrm{PO}_{4}, 1.2 \mathrm{mM} \mathrm{Na}_{2} \mathrm{SO}_{4}, 5.9 \mathrm{mM} \mathrm{KCL}, 1.25 \mathrm{mM}$ $\mathrm{CaCl}_{2}, 1.18 \mathrm{mM} \mathrm{MgCl}_{2}$, and $6 \mathrm{mM}$ glucose, $\mathrm{pH} \sim 7.3$ ) was used for the experiments. Pd phosphor solution $(2.5 \mathrm{mg} /$ $\mathrm{mL}=2 \mathrm{mM}$ ) was prepared in $\mathrm{dH}_{2} \mathrm{O}$ and stored in aliquots at $-20^{\circ} \mathrm{C}$. NaCN solution $(1.0 \mathrm{M})$ was prepared in $\mathrm{dH}_{2} \mathrm{O}$; its $\mathrm{pH}$ was adjusted to $\sim 7.0$ with $12 \mathrm{~N} \mathrm{HCl}$ and the solution was then stored at $-20^{\circ} \mathrm{C}$. 


\section{Mice}

Male Taylor outbred mice (8-12-wk-old; weight $\approx 18-22 \mathrm{~g}$ ) used in this study were maintained at an animal facility that was in compliance with National Institutes of Health guidelines (http:// grants.nih.gov/grants/olaw/references/phspol.htm). The mice were purchased from the Jackson Laboratory (Bar Harbor, ME, USA). All mice were housed in rooms maintained at $22^{\circ} \mathrm{C}$ with $\sim 60 \%$ relative humidity and a 12-hour light/dark cycle. All mice had ad libitum access to standard rodent chow and filtered water. All the protocols used in the studies here received approval from the Animal Ethics Committee, United Arab Emirates University College of Medicine and Health Sciences.

\section{In vitro incubation}

Lung specimens (about $20 \mathrm{mg}$ each) were excised from anesthetized (urethane, $100 \mu \mathrm{L} / 10 \mathrm{~g}$ body weight, using $25 \%$ solution, in $0.9 \% \mathrm{NaCl}$ ) mice using sharp scissors. The specimens were immediately immersed in ice-cold $\mathrm{KH}$ buffer continuously gassed with $95 \% \mathrm{O}_{2}: 5 \% \mathrm{CO}_{2}$. The incubation mixture $(50 \mathrm{~mL})$ contained the same buffer with and without 0.2 or $1.0 \mathrm{mg} / \mathrm{mL}$ nanoparticles. ${ }^{15}$

\section{Intratracheal instillation}

Particles were intratracheally instilled as previously described with minor modifications. ${ }^{23}$ Briefly, mice were anesthetized with an intraperitoneal injection of $70 \mu \mathrm{g} / \mathrm{g}$ pentobarbital. Particles were suspended in $150 \mu \mathrm{L}$ of $0.9 \% \mathrm{NaCl}$ and instilled using a 20-gauge cannula (Venflon; BD, Franklin Lakes, NJ, USA). The control mice had $150 \mu \mathrm{L}$ of $0.9 \% \mathrm{NaCl}$ instilled in their trachea. One hour after treatment, the mice were killed, and lung specimens were collected and processed as above.

\section{Histology}

Tissue was fixed using $10 \%$ neutral formalin, dehydrated using increasing concentrations $(50 \%, 70 \%, 90 \%$, and $100 \%)$ of ethanol, cleared with xylene and embedded in paraffin. Three-micrometer sections were prepared from paraffin blocks and stained with hematoxylin and eosin.

Staining for apoptosis was performed using a method involving avidin-biotin immunoperoxidase that can detect activated caspase-3 (Cell Signaling Technology, Boston, MA, USA). The procedure was performed on 5- $\mu \mathrm{m}$ paraffin sections, using rabbit anti-cleaved caspase- 3 antibodies; positive control was human breast cancer.

\section{Electron microscopy}

Tissue was immersed in McDowell and Trump fixative for 3 hours at $25^{\circ} \mathrm{C}$. The tissue was then rinsed with phosphate buffer saline and fixed with $1 \%$ osmium tetroxide for 1 hour. Samples were washed with $\mathrm{dH}_{2} \mathrm{O}$, dehydrated in graded ethanol and propylene oxide, infiltrated, embedded in agar-100 epoxy resin and polymerized at $65^{\circ} \mathrm{C}$ for 24 hours. Blocks were trimmed, and semithin and ultrathin sections were cut with a Reichert-Jung Ultracut Ultramicrotome (Leica Microsystems, Wetzlar, Germany). The semithin sections $(1 \mu \mathrm{m})$ were placed on glass slides and stained with $1 \%$ aqueous toluidine blue. The ultrathin sections $(95 \mathrm{~nm})$ on 200 -mesh $\mathrm{Cu}$ grids were contrasted with uranyl acetate followed by lead citrate double stain. The grids were examined and imaged using a CM10 transmission electron microscope (Philips, Amsterdam, Netherlands).

\section{Oxygen measurement}

A phosphorescence $\mathrm{O}_{2}$ analyzer was used to monitor $\mathrm{O}_{2}$ consumption by lung specimens, as reported previously. Briefly, $\mathrm{O}_{2}$ detection was performed with the aid of $\mathrm{Pd}$ phosphor, which had an absorption maximum at $625 \mathrm{~nm}$ and a phosphorescence maximum at $800 \mathrm{~nm}$. Samples were exposed to light flashes (600 per minute) from a pulsed lightemitting diode array with peak output at $625 \mathrm{~nm}$ (OTL630A5-10-66-E; Opto Technology, Wheeling, IL, USA). The emitted phosphorescent light was detected by a Hamamatsu Photonics (Hamamatsu, Japan) photomultiplier tube (R928) after first passing the light through a wide-band interference filter centered at $800 \mathrm{~nm}$. The amplified phosphorescence decay was digitized at $1.0 \mathrm{MHz}$ by a $20 \mathrm{MHz} \mathrm{A} / \mathrm{D}$ converter (Computer Boards, Inc.).

A program was developed using Microsoft Visual Basic 6, Microsoft Access Database 2007, and Universal Library components (Universal Library for Measurements Computing Devices, http://www.mccdaq.com/daq-software/ universal-library.aspx). This allowed direct reading from the PCI-DAS 4020/12 I/O Board (PCI-DAS 4020/12 I/O Board, http://www.mccdaq.com/pci-data-acquisition/PCIDAS4020-12.aspx). Pulse detection was accomplished by searching for ten phosphorescence intensities $>1.0 \mathrm{~V}$ (by default). Peak detection was accomplished by searching for the highest ten data points of a pulse and choosing the data point closest to the pulse-decay curve. ${ }^{17}$

The phosphorescence decay rate $(1 / \tau)$ was characterized by a single exponential, ie, $\mathrm{I}=\mathrm{Ae}^{-t / \tau}$, where $\mathrm{I}=\mathrm{Pd}$ phosphor phosphorescence intensity. ${ }^{24}$ The values of $1 / \tau$ were linear with dissolved $\mathrm{O}_{2}: 1 / \tau=1 / \tau^{\circ}+k_{q}$, where $1 / \tau=$ the phosphorescence decay rate in the presence of $\mathrm{O}_{2}, 1 / \tau^{\circ}=$ the phosphorescence decay rate in the absence of $\mathrm{O}_{2}$, and $k_{\mathrm{q}}=$ the second-order $\mathrm{O}_{2}$ quenching rate constant in $\mu \mathrm{M} /$ second. $^{24}$ 
Lung tissue respiration was measured at $37^{\circ} \mathrm{C}$ in $1 \mathrm{~mL}$ sealed vials by stirring the lung specimen with the aid of parylene-coated stirring bars. In vials sealed from air, $\mathrm{O}_{2}$ decreased linearly with time, indicating the kinetics of mitochondrial $\mathrm{O}_{2}$ consumption was zero-order. The rate of respiration ( $k$, in $\mu \mathrm{M} \mathrm{O}_{2}$ /minute) was thus the negative of the slope $\mathrm{d}\left(\mathrm{O}_{2}\right) / \mathrm{d} t$. Sodium cyanide was used to crosscheck the process or to determine if $\mathrm{O}_{2}$ was consumed by the mitochondrial respiratory chain; this is possible because sodium cyanide kills the cells and inhibits their mitochondrial respiration. ${ }^{15}$

\section{ATP content}

Lung tissue fragments were homogenized in $0.5 \mathrm{~mL}$ of ice-cold $2 \%$ trichloroacetic acid for 2 minutes. The supernatants were collected by centrifugation $\left(1000 \times g\right.$ at $4^{\circ} \mathrm{C}$ for 5 minutes $)$ and stored at $-20^{\circ} \mathrm{C}$ until analysis. Immediately before ATP measurements, the samples were neutralized with $0.5 \mathrm{~mL}$ $100 \mathrm{mM}$ Tris-acetate, $2 \mathrm{mM}$ ethylenediaminetetraacetic acid (final $\mathrm{pH}$ 7.75). ATP concentration was determined using the Enliten ATP Assay System (Bioluminescence Detection Kit; Promega, Madison, WI, USA). Briefly, $2.5 \mu \mathrm{L}$ of the supernatant was added to $25 \mu \mathrm{L}$ of the luciferin/luciferase reagent. The luminescence intensity was measured at $25^{\circ} \mathrm{C}$ using a Glomax Luminometer (Promega). The standard curve of luminescence intensity vs ATP concentration $(10 \mathrm{pM}$ to $100 \mathrm{nM})$ was linear $\left(R^{2}>0.9999\right)$. Variations in the luminescence intensity between experiments were due to aging of the reagents.

\section{Intracellular caspase-3 activity}

Lung specimens ( $\sim 25 \mathrm{mg}$ ) were collected from the Taylor outbred mice and incubated in vitro at $37^{\circ} \mathrm{C}$ in $50 \mathrm{~mL} \mathrm{KH}$ buffer continuously gassed with $95 \% \mathrm{O}_{2}: 5 \% \mathrm{CO}_{2}$ with and without nanoparticles for up to 6 hours. Samples were removed from the incubation mixture, rinsed with $\mathrm{KH}$ buffer, and incubated in oxygenated KH buffer with $32 \mu \mathrm{M}$ zVADfmk (pancaspase inhibitor) or $15 \mu \mathrm{L}$ DMSO (the vehicle of zVAD-fmk) for 10 minutes $(\mathrm{f} / \mathrm{v}=1.0 \mathrm{~mL})$. Ac-DEVD-AMC $(37 \mu \mathrm{M})$ was then added, and the incubation continued for 20 minutes. At the end of the incubation period, the tissue was disrupted by vigorous homogenization and was passed through a $27 \mathrm{G}$ needle. The Ac-DEVD-AMC cleavage reaction was quenched with tissue disruption, mainly because caspases became inactive due to dilution. The supernatant was collected by centrifugation $(\sim 16,300 \times g$ for 90 minutes) through a Microcentrifuge Filter (nominal molecular weight limit $=10,000$ Dalton; Sigma-Aldrich), separated on HPLC, and analyzed for the free fluorogenic AMC moiety.

\section{HPLC}

The analysis was performed on a Waters (Milford, MA, USA) reversed-phase HPLC system, which consisted of a manual injector, a pump, and a fluorescent detector. An excitation wavelength of $380 \mathrm{~nm}$ and an emission wavelength of $460 \mathrm{~nm}$ were chosen or used for the experiments. Solvents A and B were HPLC-grade methanol: $\mathrm{dH}_{2} \mathrm{O}$ 1:1 (isocratic). Alternatively, solvent A was 1:3 ratio of HPLC-grade $\mathrm{CH}_{3} \mathrm{CN}: \mathrm{dH}_{2} \mathrm{O}$ and solvent $\mathrm{B}$ was $\mathrm{dH}_{2} \mathrm{O}$ (isocratic); both protocols gave the same results. The column, a $4.6 \times 250 \mathrm{~mm}$ Beckman Ultrasphere IP column (BD), was operated at $25^{\circ} \mathrm{C}$ at $1.0 \mathrm{~mL} /$ minute $(0.5 \mathrm{~mL} /$ minute for each pump). The run time was 45 minutes, and the injection volume was $20 \mu \mathrm{L}$.

\section{Synthesis of nanoparticles}

The core-shell nanoparticles studied here were synthesized by adopting the previously reported synthetic method that led to carbon/silica core-shell nanoneedles $(\mathrm{CNNs}){ }^{25}$ In the synthesis, cellulose nanofibers were first prepared from sisal (Agave sisalana) by acid hydrolysis of bulk cellulose. ${ }^{26}$ The resulting cellulose nanofibers were used as the precursor of carbon (and as the core material) in the final nanoparticles.

In typical synthesis, $14 \mathrm{~g}$ of natural sisal fiber was cut and washed with $400 \mathrm{~mL}$ solution of toluene:ethanol (1:1 ratio) under reflux for 12 hours. The solid material was recovered from the solution by filtration and dried at room temperature. The recovered solid was treated with $1 \mathrm{M} \mathrm{NaOH}$ solution $(300 \mathrm{~mL})$ for 12 hours, after which the mixture was filtered. The resulting solid material was then treated with $3 \%$ aqueous $\mathrm{H}_{2} \mathrm{O}_{2}$ solution ( $100 \mathrm{~mL}$ ) for 6 hours, and the mixture was filtered. This treatment of the solid material with $\mathrm{NaOH}$ and $\mathrm{H}_{2} \mathrm{O}_{2}$ alternatively was repeated three times. The resulting material (pure bulk cellulose) was washed several times with water to completely remove any residual $\mathrm{NaOH}$ and $\mathrm{H}_{2} \mathrm{O}_{2}$ off the cellulose nanofibers.

The bulk cellulose $(2 \mathrm{~g})$ was then mixed with $80 \mathrm{~mL}$ of $65 \%$ sulfuric acid solution, and the mixture was stirred at $72^{\circ} \mathrm{C}$ for 30 minutes at $800 \mathrm{rpm}$. The resulting mixture was centrifuged for 5 minutes at $5000 \mathrm{rpm}$. The supernatant was decanted, and the precipitate was recovered and redispersed in water. Centrifugation of the mixture and redispersion of the precipitate in distilled water were repeated until the liquid phase became opaque. The liquid phase and the solid were then sonicated for 6 hours. The mixture was centrifuged again at $5000 \mathrm{rpm}$ for 5 minutes. The liquid phase was collected 
and centrifuged for 15 minutes at 12,000 rpm, producing cellulose nanofibers. The resulting cellulose nanofibers were dispersed in water to obtain $80 \mathrm{~mL}$ solution.

The cellulose nanofibers were then coated with silica shells as follows. First, $12 \mathrm{~mL}$ of the above solution containing the cellulose nanofibers was dispersed in $100 \mathrm{~mL}$ of absolute ethanol. Into this mixture, $5 \mathrm{~mL}$ of $\mathrm{NH}_{3}$ solution (28\%) was added. After stirring the mixture with a magnetic stirrer for 1 hour, followed by sonication in an ultrasonicator bath for 5 minutes, $100 \mu \mathrm{L}$ of tetraethyl orthosilicate was added into it. The mixture was sonicated further for 30 minutes, and then stirred with a magnetic stirrer for another 12 hours. The resulting solid material was recovered from the solution by centrifugation, dried in an oven, and ground into powder using a mortar and pestle. The solid powdered material was calcined at $1200^{\circ} \mathrm{C}$ for 3 hours, generating the $\mathrm{C}-\mathrm{SiO}_{2}$ coreshell nanoparticles. By treating $50 \mathrm{mg}$ of the $\mathrm{C}-\mathrm{SiO}_{2}$ sample with $50 \mathrm{~mL}$ of $1.0 \mathrm{M} \mathrm{NaOH}$ solution for 2 hours, the silica shell from the material was removed, leaving behind carbon nanoparticles, labeled as $\mathrm{C}-\mathrm{SiO}_{2}$-etched.

The cobalt-containing carbon nanoparticles were synthesized by following a similar procedure as above, except $\mathrm{Co}\left(\mathrm{NO}_{3}\right)_{2}$ was added along with tetraethyl orthosilicate during the deposition step of the silica shells. Specifically, into $12 \mathrm{~mL}$ dispersion of cellulose nanofibers, $50 \mathrm{mg}$ of $\mathrm{Co}\left(\mathrm{NO}_{3}\right)_{2} \cdot 6 \mathrm{H}_{2} \mathrm{O}$ was added, followed by $100 \mu \mathrm{L}$ of tetraethyl orthosilicate in $100 \mathrm{~mL}$ of absolute ethanol. The resulting material was treated under different calcination temperatures to obtain samples containing different phases of cobalt. The $\mathrm{C}-\mathrm{Co}-\mathrm{SiO}_{2}$ core-shell-shell nanoparticles were obtained by treating the above material at $1100^{\circ} \mathrm{C}$ for 3 hours whereas the $\mathrm{C}-\mathrm{Co}_{3} \mathrm{O}_{4}-\mathrm{SiO}_{2}$ core-shell-shell nanoparticles were obtained by treating the material at $1000^{\circ} \mathrm{C}$ for 3 hours.

\section{Dynamic light scattering}

To analyze the size of the nanoparticles further, dynamic light-scattering (DLS) experiments were performed on the samples using a Zetasizer Nano ZS90 (Malvern Instruments, Malvern, UK). The DLS measurements were carried out at a scattering angle of $90^{\circ}$ and at $25^{\circ} \mathrm{C}$. Prior to the DLS measurements, the nanoparticles $(5 \mathrm{mg})$ were dispersed in water $(5 \mathrm{~mL})$, and the mixture was sonicated in a bath sonicator to form well-dispersed nanoparticles. The dispersion $(2 \mathrm{~mL})$ was then placed in a polystyrene cuvette having an optical path length of $1 \mathrm{~cm}$ and measured by DLS. The reported values or data represent the average of three runs for each sample.

\section{Statistical analysis}

Data were analyzed using SPSS statistical package version 19 (IBM, Armonk, NY, USA). The nonparametric (two independent variables) Mann-Whitney test was used to compare treated and untreated samples.

\section{Results \\ Properties of nanoparticles}

The structural features and composition of the nanoparticles synthesized above were characterized by using various analytical techniques, including powder X-ray diffraction (XRD), Fourier-transform infrared spectroscopy (FTIR), Raman spectroscopy, DLS, and transmission electron microscopy (TEM). The results are compiled in Table 1, including the TEM images of the samples. Additional characterization data are presented in Supplementary materials (Figures $\mathrm{S} 1-\mathrm{S} 3$ ). The powder XRD patterns of $\mathrm{C}-\mathrm{SiO}_{2}$ and $\mathrm{C}-\mathrm{SiO}_{2}$ showed no diffraction patterns indicating that these two materials were exclusively amorphous. However, the powder XRD patterns of $\mathrm{Co}-\mathrm{SiO}_{2}$ and $\mathrm{C}-\mathrm{Co}_{3} \mathrm{O}_{4}-\mathrm{SiO}_{2}$ nanoparticles showed some diffraction peaks corresponding to metallic $\mathrm{Co}$ and $\mathrm{Co}_{3} \mathrm{O}_{3}$, respectively. Comparative FTIR spectra of unetched and etched nanoparticles (eg, $\mathrm{C}-\mathrm{SiO}_{2}$ versus $\mathrm{C}-\mathrm{SiO}_{2}$-etched nanoparticles) showed significant differences. Whereas a strong $\mathrm{Si}-\mathrm{O}$ stretching band at around $1100 \mathrm{~cm}^{-1}$ that is characteristic of $\mathrm{SiO}_{2}$ was observed in the FTIR spectrum of $\mathrm{C}-\mathrm{SiO}_{2}$, no such band was observed in the FTIR spectrum of $\mathrm{C}-\mathrm{SiO}_{2}$-etched. This clearly suggests that the silica shells around the $\mathrm{C}-\mathrm{SiO}_{2}$ core-shell nanoparticles were completely removed after treatment of these nanoparticles with dilute $\mathrm{NaOH}$ solution.

From Table 1, it is also worth noting that the cobalt ions encapsulated within the core-shell nanoparticles were turned into either metallic $\mathrm{Co}$ or $\mathrm{Co}_{3} \mathrm{O}_{4}$ nanoparticles simply by changing the pyrolysis temperature employed during the synthesis. The thermal treatment also allowed the cellulose to convert to amorphous or graphitic carbon. Thus, by varying the pyrolysis temperature as well as the synthetic conditions, different samples that enabled us to investigate composition-dependent cytotoxicity of the nanoparticles were obtained.

\section{$\mathrm{C}-\mathrm{SiO}_{2}$-etched nanoparticles}

The effects of $\mathrm{C}-\mathrm{SiO}_{2}$-etched nanoparticles on lung tissue respiration, ATP content, caspase activity, and structure were investigated following in vitro and in vivo treatments. The in vitro doses were $0.2 \mathrm{mg} / \mathrm{mL}$ (Figure 1) and $1.0 \mathrm{mg} / \mathrm{mL}$ (Figure S4 in Supplementary materials), and the in vivo 
Table I Physical properties of the carbon-, cobalt-, and silica-based nanomaterials studied

\begin{tabular}{|c|c|c|c|c|}
\hline Analytical method & $\mathrm{C}-\mathrm{SiO}_{2}$-etched & $\mathrm{C}-\mathrm{SiO}_{2}$ & $\mathrm{C}-\mathrm{Co}-\mathrm{SiO}_{2}$ & $\mathrm{C}-\mathrm{Co}_{3} \mathrm{O}_{4}-\mathrm{SiO}_{2}$ \\
\hline Powder X-ray diffraction & Amorphous carbon & $\begin{array}{l}\text { Amorphous carbon core } \\
\text { with amorphous silica } \\
\text { shell }\end{array}$ & $\begin{array}{l}\text { Graphitic-like carbon; presence } \\
\text { of metallic cobalt }\end{array}$ & $\begin{array}{l}\text { Graphitic-like carbon; } \\
\mathrm{Co}_{3} \mathrm{O}_{4} \text { nanoparticles } \\
\text { sandwiched between } \\
\mathrm{C} \text { core and } \mathrm{SiO}_{2} \\
\text { shell }\end{array}$ \\
\hline Raman spectroscopy & Amorphous carbon & Amorphous carbon & Graphitic carbon & Graphitic carbon \\
\hline $\begin{array}{l}\text { Transmission electron } \\
\text { microscopy }\end{array}$ & $\begin{array}{l}\text { Amorphous structures } \\
\text { of carbon; appeared } \\
\text { aggregated }\end{array}$ & $\begin{array}{l}\text { Amorphous structures } \\
\text { of carbon; appeared highly } \\
\text { aggregated }\end{array}$ & $\begin{array}{l}\text { Carbon/silica core-shell } \\
\text { nanowires with metallic Co } \\
\text { nanoparticles embedded inside }\end{array}$ & $\begin{array}{l}\text { Long nanowires having } \\
\mathrm{C}-\mathrm{Co}_{3} \mathrm{O}_{4}-\mathrm{SiO}_{2} \text { core- } \\
\text { shell-shell structures }\end{array}$ \\
\hline & sut & 2000 & 20 & $\underline{\underline{200}}$ \\
\hline $\begin{array}{l}\text { Average particle size } \\
\text { determined by dynamic } \\
\text { light scattering }(D L S)^{a}\end{array}$ & $299.5 \mathrm{~nm}$ & $332.7 \mathrm{~nm}$ & $1609.7 \mathrm{~nm}$ & $463.7 \mathrm{~nm}$ \\
\hline
\end{tabular}

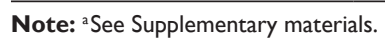

doses were $5 \mathrm{mg} / \mathrm{mL}$ (Figure 1) and $10 \mathrm{mg} / \mathrm{mL}$ (Figure S4 and Table S1 in Supplementary materials).

For the in vitro treatment, lung specimens (16-27 mg) were incubated at $37^{\circ} \mathrm{C}$ in oxygenated $\mathrm{KH}$ buffer with and without 0.2 or $1.0 \mathrm{mg} / \mathrm{mL} \mathrm{C}-\mathrm{SiO}_{2}$-etched nanoparticles. Samples were then alternatively removed from the incubation mixture, rinsed with $\mathrm{KH}$ buffer, and placed in the phosphorescence analyzer to measure the concentration of $\mathrm{O}_{2}$ at $37^{\circ} \mathrm{C}$. Representative runs for the specimens treated with the $0.2 \mathrm{mg} / \mathrm{mL}$ dose are shown in Figure 1A, and a summary of all the results is given in Figure $1 \mathrm{~B}$. The rate of pneumatocyte mitochondrial $\mathrm{O}_{2}$ consumption (mean \pm standard deviation, rate of cellular respiration $\left[k_{c}\right]$, in $\mu \mathrm{M} \mathrm{O}_{2} /$ minute $/ \mathrm{mg})$ for untreated tissue was $0.187 \pm 0.042(\mathrm{n}=33)$ and for treated tissue was $0.186 \pm 0.036(n=11, P=0.957)$. Similar results were obtained with in vitro treatment of the specimens with $1.0 \mathrm{mg} / \mathrm{mL}$ dosage (Figure S4A and B in Supplementary materials). Cellular ATP contents for $1 \leq t \leq$ 5 were consistently found to be similar in treated and untreated specimens (Figure S4B and Table S1 in Supplementary materials). The sharp decline in cellular ATP and the lower rate of respiration for $t=0$ demonstrated the inability to sustain in vivo levels of pneumatocyte bioenergetics (Figure S4B in Supplementary materials). Otherwise, the data indicated reasonable biocompatibility of $\mathrm{C}-\mathrm{SiO}_{2}$-etched nanoparticles with pneumatocyte bioenergetics.

Caspase activity was also monitored in treated and untreated lung specimens. The synthetic caspase-3 substrate Ac-DEVD-AMC was used for this purpose. Lung specimens were incubated in vitro at $37^{\circ} \mathrm{C}$ in oxygenated $\mathrm{KH}$ buffer with

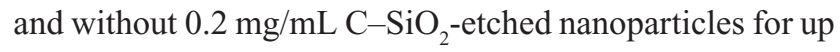
to 5 hours. The samples were then rinsed and incubated with Ac-DEVD-AMC for 20 minutes in the presence and absence of the pan-caspase inhibitor zVAD-fmk. Caspases cleaved Ac-DEVD-AMC, releasing the fluorogenic moiety AMC. After tissue disruption, the supernatants were separated on HPLC, and the AMC moieties were detected by fluorescence. The AMC peak area (arbitrary units $/ 10^{6} \mathrm{mg}$ ) markedly increased at $t \geq 4$ hours in the tissue treated with $\mathrm{C}-\mathrm{SiO}_{2}-$ etched sample. zVAD-fmk blocked $\sim 87 \%$ of the AMC cleavage reaction, confirming that the reaction was mainly mediated by caspases (Figure 1C).

Lung histology was studied immediately ( 0 hour) and 2, 3, 4, and 5 hours after the tissue was incubated with the nanoparticles. Representative images taken 4 hours after incubation are shown in Figure $1 \mathrm{G}$ and H. Alveolar structure remained preserved in the untreated specimen (Figure 1G). The specimen treated with $\mathrm{C}-\mathrm{SiO}_{2}$-etched nanoparticles, on 


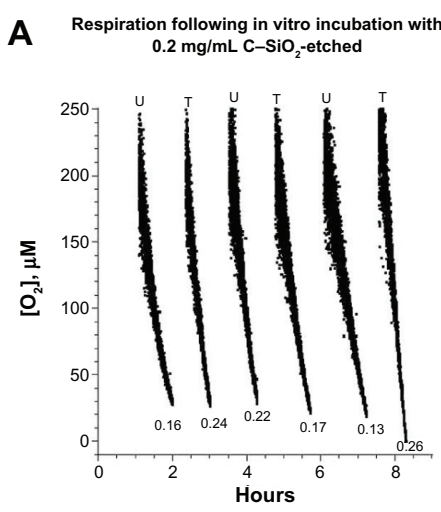

D $\begin{aligned} & \text { Respiration following intratracheal } \\ & \text { installation of } 5 \mathrm{mg} \mathrm{C}-\mathrm{SiO}_{2} \text {-etched }\end{aligned}$

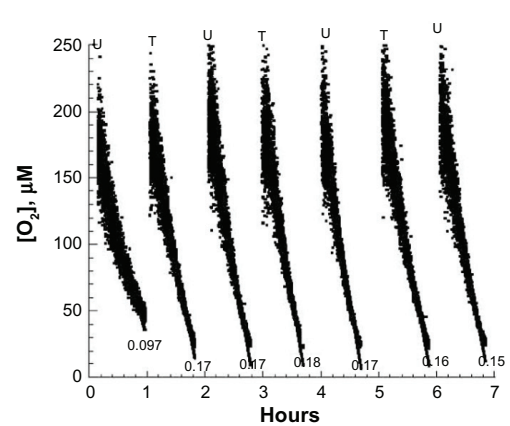

G

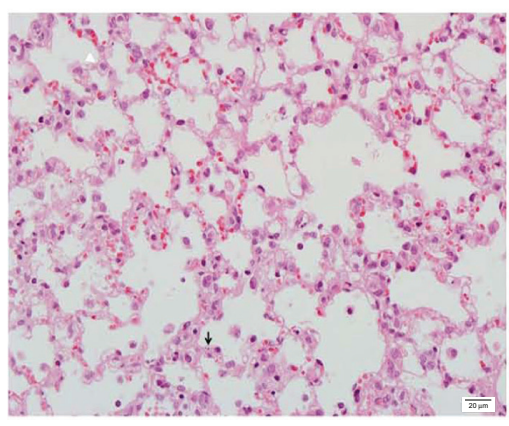

B

Respiration following in vitro incubation with

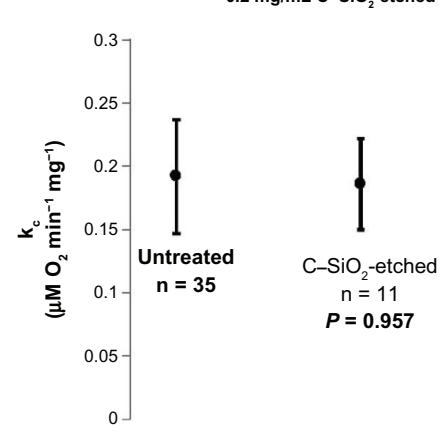

E

Respiration and ATP content following intratracheal
installation of $15 \mathrm{mg} \mathrm{C}-\mathrm{SiO}_{2}$-etched

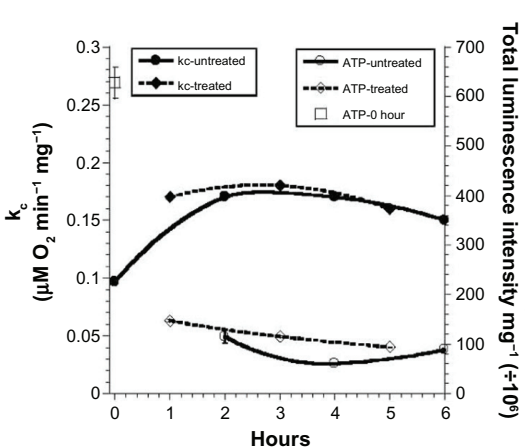

H In vitro incubation with $0.2 \mathrm{mg} / \mathrm{mL}$

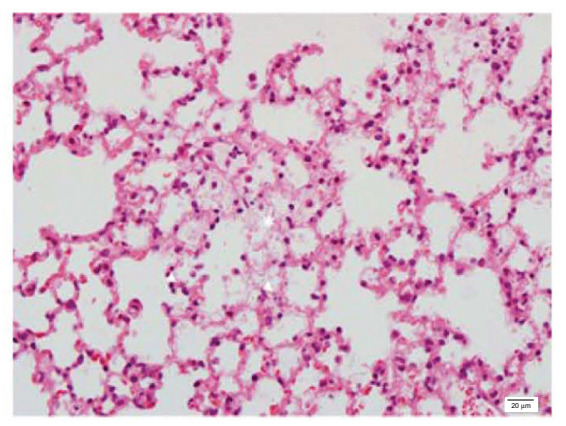

C Caspase activity following in vitro incubation with
$0.2 \mathrm{mg} / \mathrm{mL} \mathrm{C}-\mathrm{SiO}_{2}$-etched

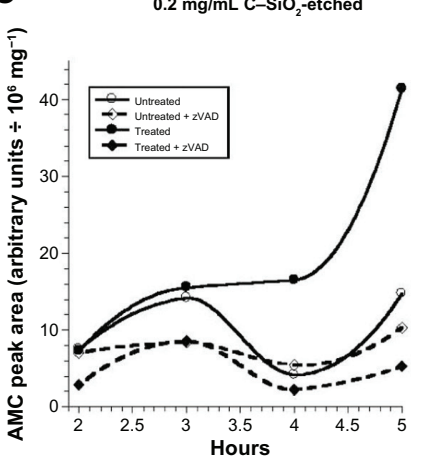

F $\begin{gathered}\text { Caspase activity following intratracheal } \\ \text { installation of } 5 \mathrm{mg} \mathrm{C}-\mathrm{SiO}_{2} \text {-etched }\end{gathered}$

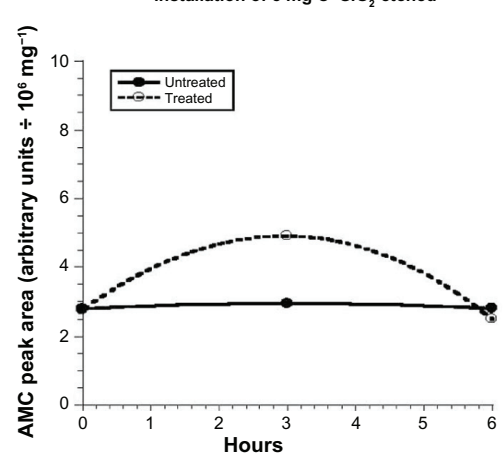

Intratracheal instillation of $5 \mathrm{mg}$ $\mathrm{C}-\mathrm{SiO}_{2}$-etched

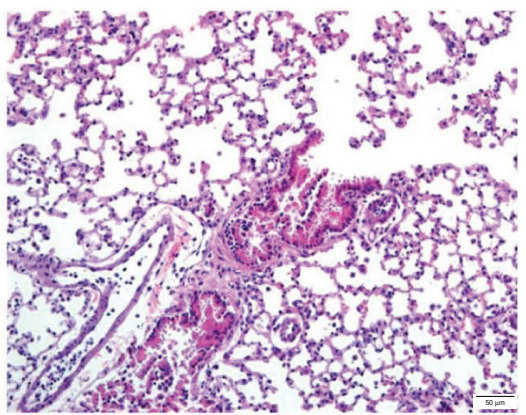

Figure I (A-I) Biocompatibility of $\mathrm{C}-\mathrm{SiO}_{2}$-etched nanoparticles with lung respiration, adenosine triphosphate (ATP) content, caspase activity, and histology. (A-C) Lung

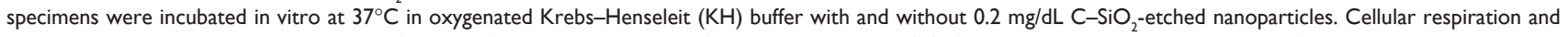
caspase activity were then measured as a function of time. Representative $\mathrm{O}_{2}$ runs are shown in (A). Samples were alternatively removed from the incubation mixture, rinsed with $\mathrm{KH}$ buffer, and immediately placed in the phosphorescence analyzer for $\mathrm{O}_{2}$ measurement. Minute zero corresponds to the addition of the $\mathrm{C}-\mathrm{SiO} \mathrm{O}_{2}$-etched sample. The rate of pneumatocyte mitochondrial $\mathrm{O}_{2}$ consumption $\left(k, \mu \mathrm{M} \mathrm{O}_{2} /\right.$ minute) is set as the negative of the slope of $\mathrm{O}_{2}$ vs $t$; the values of $k_{c}$ (in $\mu \mathrm{M} \mathrm{O}_{2} / \mathrm{minute} / \mathrm{mg}$ ) are shown at the bottom of each run $\left(\mathrm{U}\right.$, untreated; $\mathrm{T}$, treated). A summary of the values of $k_{c}$ for all experiments is shown in (B). The $P$-value is for comparison with the untreated condition; " $n$ " is the number of independent measurements. Caspase activity with and without the pancaspase inhibitor zVAD-fmk is shown in (C). (D-F) Lung specimens were collected 60 minutes after intratracheal instillation of $5 \mathrm{mg} \mathrm{C}-\mathrm{SiO}_{2}$-etched sample or $150 \mu \mathrm{L} \mathrm{NaCl}$. The samples were then incubated in vitro at $37^{\circ} \mathrm{C}$ in oxygenated $\mathrm{KH}$ buffer. Cellular respiration, ATP content, and caspase activity $(\mathbf{F})$ were measured as a function of time. Representative $\mathrm{O}_{2}$ runs, values of $k_{c}$, and cellular ATP (expressed as

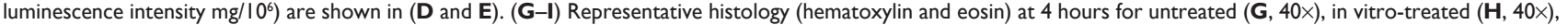
and intratracheally treated (I, 20x) lungs. The untreated lung tissue (G) demonstrated preserved pulmonary architecture with rare apoptotic bodies (arrow) and cytoplasmic vacuolization (arrowhead). The in vitro treatment $\mathbf{( H )}$ revealed foci of alveolar wall necrosis necrosis and a few apoptotic bodies. The in vivo treatment $(\mathbf{I})$ revealed preserved pulmonary architecture with focal sloughing of bronchial epithelial cells, intact alveolar wall and intravascular margination of lymphoid cells.

the other hand, showed foci of alveolar wall necrosis and a few apoptotic bodies (Figure 1H). Similar alterations were seen in the specimen treated with $1.0 \mathrm{mg} / \mathrm{mL} \mathrm{C}-\mathrm{SiO}_{2}$-etched nanoparticles (Figure S4C in Supplementary materials). Thus, the caspase activity and histology data demonstrate the cytotoxicities of the $\mathrm{C}-\mathrm{SiO}_{2}$-etched nanoparticles. These findings were further confirmed by the caspase-3 staining results (see below).

Intratracheal instillation of 5 and $10 \mathrm{mg} \mathrm{C}-\mathrm{SiO}_{2}$-etched nanoparticles was then investigated. Intratracheal instillation 
of $150 \mu \mathrm{L} 0.9 \% \mathrm{NaCl}$ was done for the control mice. Lung specimens were collected 1 hour after treatment with $\mathrm{C}-\mathrm{SiO}_{2}-$ etched sample. The specimens were then incubated at $37^{\circ} \mathrm{C}$ in oxygenated $\mathrm{KH}$ buffer, and they were then evaluated for respiration, ATP content, caspase activity, and histology as a function of time. The value of $k_{c}$ for mice treated with $0.9 \%$ $\mathrm{NaCl}$ was $0.15 \pm 0.04(\mathrm{n}=16)$, for mice treated with $5 \mathrm{mg}$ particles was $0.17 \pm 0.01(\mathrm{n}=3, P=0.634$; Figure $1 \mathrm{D}$ and $\mathrm{E})$, and for mice treated with $10 \mathrm{mg}$ particles was $0.18 \pm 0.03(\mathrm{n}=3$, $P=0.303$; Figure S4D and E in Supplementary materials).

ATP content (expressed as total luminescence intensity per $\left.\mathrm{mg} / 10^{6}\right)$ was $87.7 \pm 26.0(\mathrm{n}=3, t=2-6$ hours $)$ for mice treated with intratracheal instillation of $0.9 \% \mathrm{NaCl}$, whereas ATP content was $118.0 \pm 26(\mathrm{n}=3, t=1-5$ hours, $P=0.200)$ for mice treated with $5 \mathrm{mg}$ dosage of $\mathrm{C}-\mathrm{SiO}_{2}$-etched nanoparticles (Figure 1E). The corresponding values for mice treated with $10 \mathrm{mg}$ dosage were $383.3 \pm 39.1(\mathrm{n}=3, t=1-6$ hours $)$ and $583.3 \pm 60.6(\mathrm{n}=3, t=1-5$ hours, $P=0.100)$, respectively (Figure S4E in Supplementary materials).

Only a slight increase in the AMC peak area was noted at $t=3$ hours in mice treated with intratracheal instillation of $5 \mathrm{mg}$ particles (Figure S4D). Similarly, lung histology of the specimen treated with $\mathrm{C}-\mathrm{SiO}_{2}$-etched nanoparticles (Figure 1I) showed less pronounced structural alternations than those seen with in vitro treatment. Thus, the in vitro treatment of the specimens with $\mathrm{C}$-SiO $\mathrm{SiO}_{2}$-etched nanoparticles resulted in more toxicity than the intratracheal instillation.

\section{$\mathrm{C}-\mathrm{SiO}_{2}$ nanoparticles}

The same experiments were performed for $\mathrm{C}-\mathrm{SiO}_{2}$ nanoparticles. For the in vitro treatments, respiration rates ( $\mu \mathrm{M} \mathrm{O}_{2} /$ minute $/ \mathrm{mg}$ ) were $0.187 \pm 0.042$ without particles and $0.199 \pm 0.029(\mathrm{n}=7, P=0.463)$ with $0.2 \mathrm{mg} / \mathrm{mL} \mathrm{C}-\mathrm{SiO}_{2}$ nanoparticles (Figure $2 \mathrm{~A}$ and $\mathrm{B}$ ). Caspase activities in the cells treated with $\mathrm{C}-\mathrm{SiO}_{2}$ nanoparticles were higher than caspace activities in untreated specimens (Figure 2C). This was corroborated by results obtained from caspase- 3 staining experiments (see below). Similar findings were noted with $1.0 \mathrm{mg}$ dosage (Figure S5A-C in Supplementary materials). In vivo treatment $(5 \mathrm{mg})$ consistently showed relatively stable respiration, ATP content, and caspases for $0 \leq t \leq 6$ hours (Figure 2D-F and Figure S2D-F in Supplementary materials). Histology also confirmed that the lung structure remained preserved for both modalities of treatment (Figure $2 \mathrm{G}$ and $\mathrm{H}$, and Figure S5C in Supplementary materials). These data show reasonable biocompatibility of $\mathrm{C}-\mathrm{SiO}_{2}$ nanoparticles with murine lung (Table S1, Supplementary materials). Thus, compared to $\mathrm{C}-\mathrm{SiO}_{2}$-etched nanoparticles, caspase activity, and structural alterations were less pronounced for the nanoparticles containing silica shells $\left(\mathrm{C}-\mathrm{SiO}_{2}\right)$.

\section{$\mathrm{C}-\mathrm{Co}-\mathrm{SiO}_{2}$ and $\mathrm{C}-\mathrm{Co}_{3} \mathrm{O}_{4}-\mathrm{SiO}_{2}$ nanoparticles}

In vitro treatment of lung specimens with $0.2 \mathrm{mg} / \mathrm{mL}$ of cobalt-containing nanoparticles resulted in impairments of cellular respiration. The value of $k_{c}\left(\mu \mathrm{M} \mathrm{O}_{2}\right.$ minute/mg) for specimens without any nanoparticles was $0.187 \pm 0.042$, with $\mathrm{C}-\mathrm{Co}-\mathrm{SiO}_{2}$ nanoparticles was $0.130 \pm 0.050(\mathrm{n}=7$, $P=0.014)$, and with $\mathrm{C}-\mathrm{Co}_{3} \mathrm{O}_{4}-\mathrm{SiO}_{2}$ nanoparticles was $0.216 \pm 0.042$ ( $\mathrm{n}=7, P=0.198$; Figure 3A). Furthermore, the result (Figure $3 \mathrm{~B}$ ) indicated that the specimens treated with $\mathrm{C}-\mathrm{Co}-\mathrm{SiO}_{2}$ nanoparticles showed the highest caspase activity after $t=4$ hours (Figure 3B). The AMC peak areas (arbitrary unit $/ 10^{6}$ ) were 7.9 without particles, 47.8 (sixfold increment) with $\mathrm{C}-\mathrm{Co}-\mathrm{SiO}_{2}$ nanoparticles, and 22.9 ( $\sim$ threefold increment) with $\mathrm{C}-\mathrm{Co}_{3} \mathrm{O}_{4}-\mathrm{SiO}_{2}$ nanoparticles. In vivo treatment of the specimen (10 $\mathrm{mg}$ intratracheal instillation of $\mathrm{C}-\mathrm{Co}-\mathrm{SiO}_{2}$ nanoparticles) also resulted in inhibition of respiration; the values of $k_{c}$ progressively decreased over 4 hours (Figure $3 \mathrm{C}$ ). The values of $k_{c}$ increased over 6 hours in the presence of $\mathrm{C}-\mathrm{Co}_{3} \mathrm{O}_{4}-\mathrm{SiO}_{2}$ nanoparticles (Figure 3D). As shown in Table $\mathrm{S} 1$ (in Supplementary materials), specimens treated with $\mathrm{C}-\mathrm{Co}_{3} \mathrm{O}_{4}-\mathrm{SiO}_{2}$ nanoparticles had increased cellular respiration but lower ATP due to uncoupling of oxidative phosphorylation. Thus, both types of cobalt containing nanoparticles $\left(\mathrm{C}-\mathrm{Co}-\mathrm{SiO}_{2}\right.$ and $\left.\mathrm{C}-\mathrm{Co}_{3} \mathrm{O}_{4}-\mathrm{SiO}_{2}\right)$ impaired lung tissue bioenergetics.

With respect to intratracheal instillation of $10 \mathrm{mg}$ nanoparticles, a marked increase in caspase activity was noted in the specimen treated with $\mathrm{C}-\mathrm{Co}-\mathrm{SiO}_{2}$ after 6 hours (Figure $3 \mathrm{E}$ and $\mathrm{F}$ ); however, caspase activity in the specimen treated with $\mathrm{C}-\mathrm{Co}_{3} \mathrm{O}_{4}-\mathrm{SiO}_{2}$ remained the same as that in the untreated specimen over $t=0-6$ hours (Figure 3E and F). Thus, caspase activity was more prominent in specimens treated with $\mathrm{C}-\mathrm{Co}-\mathrm{SiO}_{2}$ treatment.

In vitro and in vivo treatments with $\mathrm{C}-\mathrm{Co}-\mathrm{SiO}_{2}$ nanoparticles revealed alveolar wall necrosis with numerous apoptotic bodies (Figure 3G and I). The structural alterations were somewhat less pronounced with $\mathrm{C}-\mathrm{Co}_{3} \mathrm{O}_{4}-\mathrm{SiO}_{2}$ nanoparticles (Figure $3 \mathrm{H}$ and $\mathrm{J}$ ). Thus, $\mathrm{C}-\mathrm{Co}-\mathrm{SiO}_{2}$ nanoparticles were overall less biocompatible than $\mathrm{C}-\mathrm{Co}_{3} \mathrm{O}_{4}-$ $\mathrm{SiO}_{2}$ nanoparticles.

\section{Electron microscopy images}

TEM images of lung specimens incubated at $37^{\circ} \mathrm{C}$ with $200 \mu \mathrm{g} / \mathrm{mL}$ nanoparticles for 5 hours were obtained. Like the 
A

Respiration following in vitro incubation with $0.2 \mathrm{mg} / \mathrm{mL} \mathrm{C}-\mathrm{SiO}_{2}$

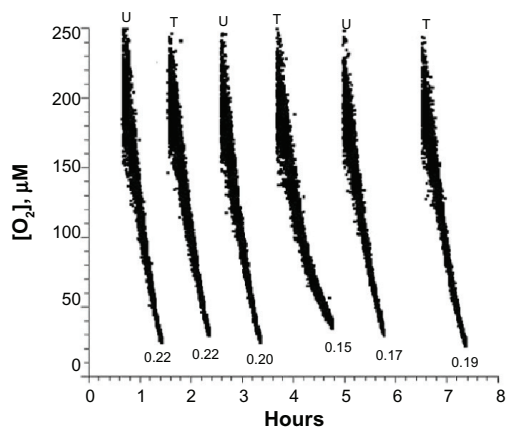

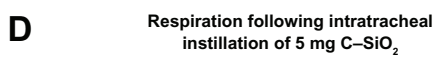

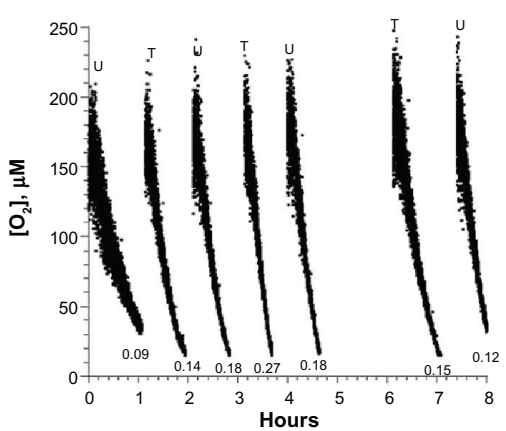

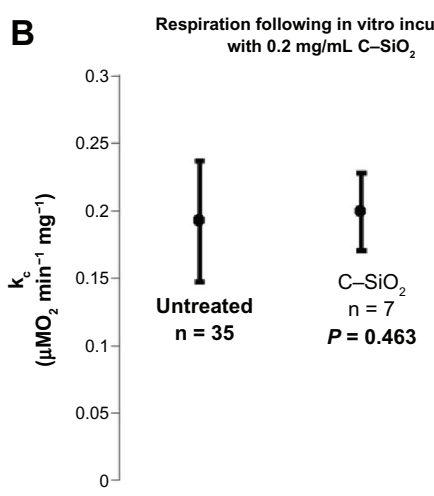

E

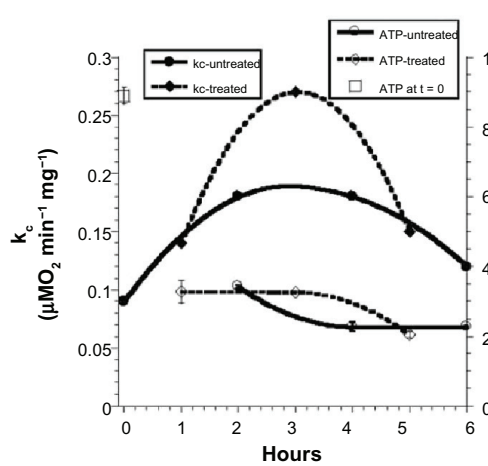

C Caspase activity following in vitro incubation

with $0.2 \mathrm{mg} / \mathrm{mL} \mathrm{C}-\mathrm{SiO}_{2}$

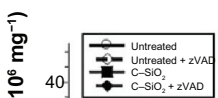

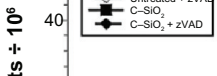

$\stackrel{?}{\stackrel{*}{\leftrightarrows}} 30$

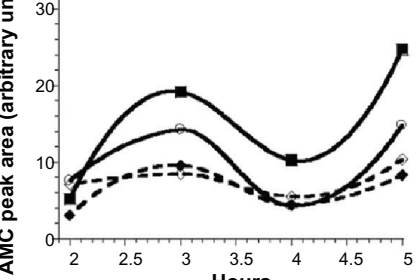

F Caspase activity following intratracheal

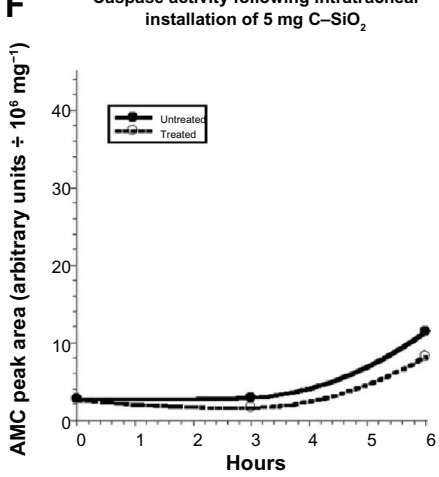

G

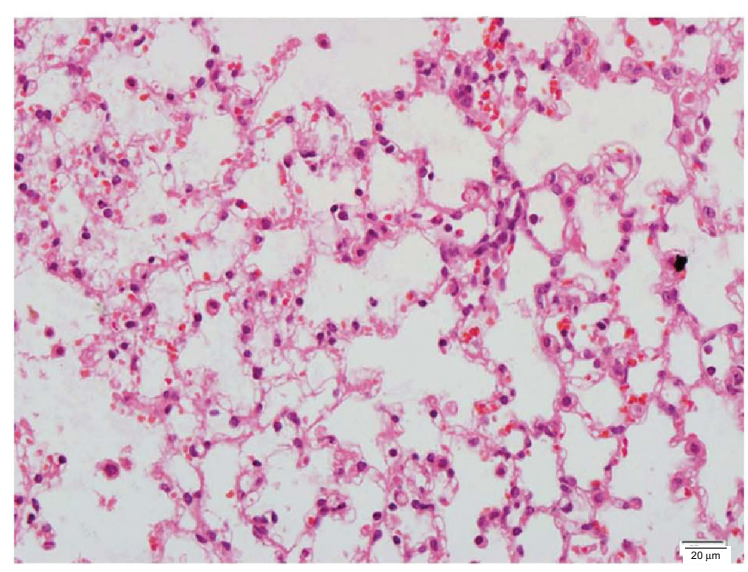

H

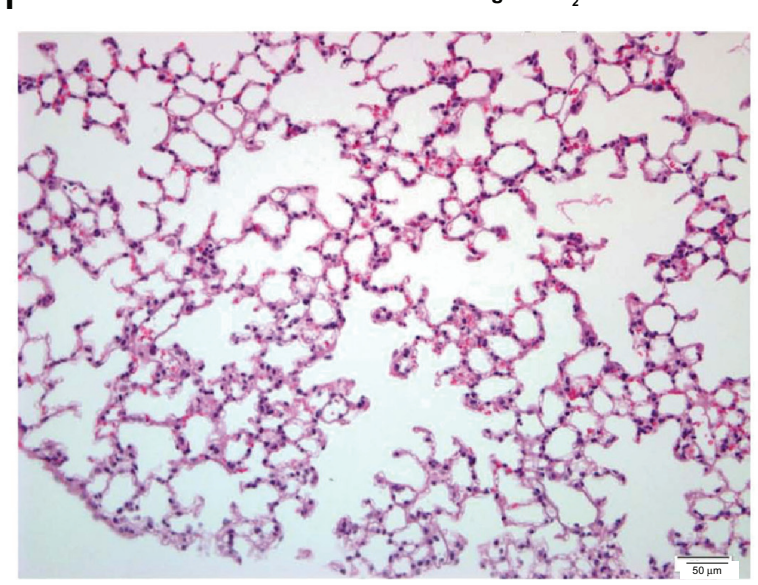

Figure $2(\mathbf{A}-\mathbf{H})$ Biocompatibility of $\mathrm{C}-\mathrm{SiO}_{2}$ with lung respiration, adenosine triphosphate (ATP) content, caspase activity, and histology. (A-C) Lung specimens were incubated in vitro at $37^{\circ} \mathrm{C}$ in oxygenated Krebs-Henseleit $(\mathrm{KH})$ buffer with and without $0.2 \mathrm{mg} / \mathrm{dL} \mathrm{C-SiO}$. Cellular respiration and caspase activity were then measured as a function of time, as described in Figure I. Representative $\mathrm{O}_{2}$ runs are shown in $(\mathbf{A})$; the values of $k_{c}\left(\mu M \mathrm{O}_{2} / \mathrm{minute} / \mathrm{mg}\right)$ are shown at the bottom of each run $(U$, untreated; $T$, treated). A summary of the values of $k_{c}$ for all experiments is shown in (B). The $P$-value is for comparison with the untreated condition; " $n$ " is the number of independent measurements. Caspase activity with and without zVAD-fmk is shown in (C). (D-F) Lung specimens were collected 60 minutes after intratracheal instillation of $5 \mathrm{mg} \mathrm{C}-\mathrm{SiO}_{2}$-etched or $150 \mathrm{~L} 0.9 \% \mathrm{NaCl}$. The samples were then incubated in vitro at $37^{\circ} \mathrm{C}$ in oxygenated $\mathrm{KH}$ buffer. Cellular respiration, ATP content and caspase activity (F) were measured as a function of time. Representative $\mathrm{O}_{2}$ runs, values of $k_{c}$, and cellular ATP are shown in (D and E). (G,H) Representative histology (hematoxylin and eosin, $40 \times$ ) at 4 hours for in vitro-treated $(\mathbf{G})$ and intratracheally treated $(\mathbf{H})$ lungs, both revealing preserved pulmonary architecture.

histology results, the TEM results indicated that $\mathrm{C}-\mathrm{Co}-\mathrm{SiO}_{2}$ and $\mathrm{C}-\mathrm{SiO}_{2}$-etched nanoparticles produced ultrastructural alterations and were toxic. In particular, $\mathrm{C}-\mathrm{Co}-\mathrm{SiO}_{2}$ was the most toxic, producing mega-mitochondria (Figure 4C) whereas $\mathrm{C}-\mathrm{SiO}_{2}$-etched nanoparticles produced apoptotic changes and swollen mitochondria (Figure 4A). Cellular ultrastructure was relatively preserved in specimens treated with $\mathrm{C}-\mathrm{SiO}_{2}$ (Figure 4B) or $\mathrm{C}-\mathrm{Co}_{3} \mathrm{O}_{4}-\mathrm{SiO}_{2}$ (Figure 4D). Staining for cleaved caspase 3 as a biomarker for apoptosis concomitantly showed abundant apoptotic cells with all of the four different types of nanoparticles studied here (Figure 5). 

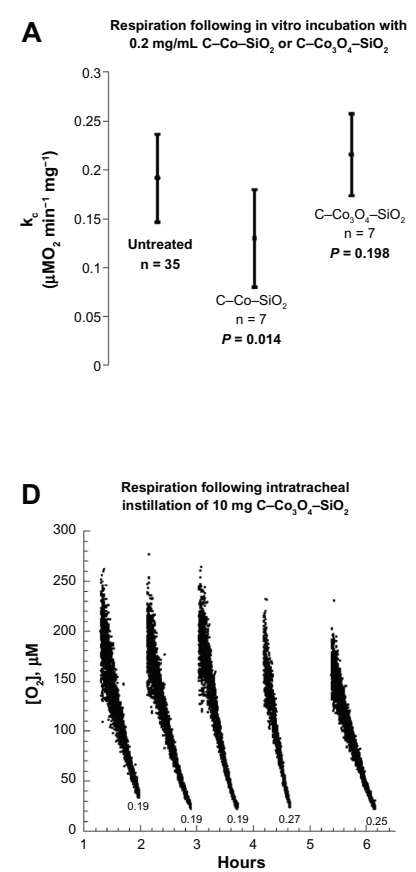
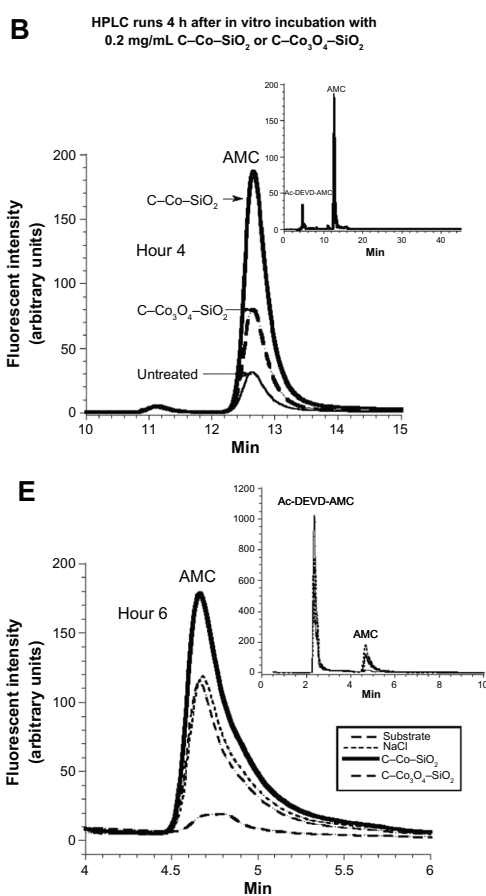
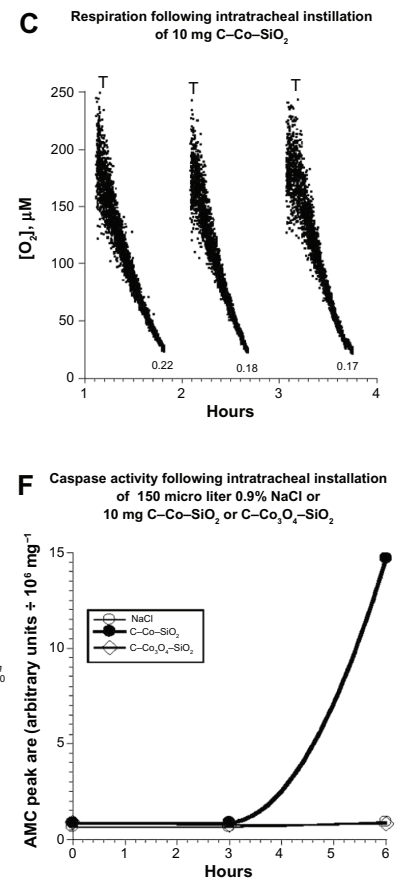
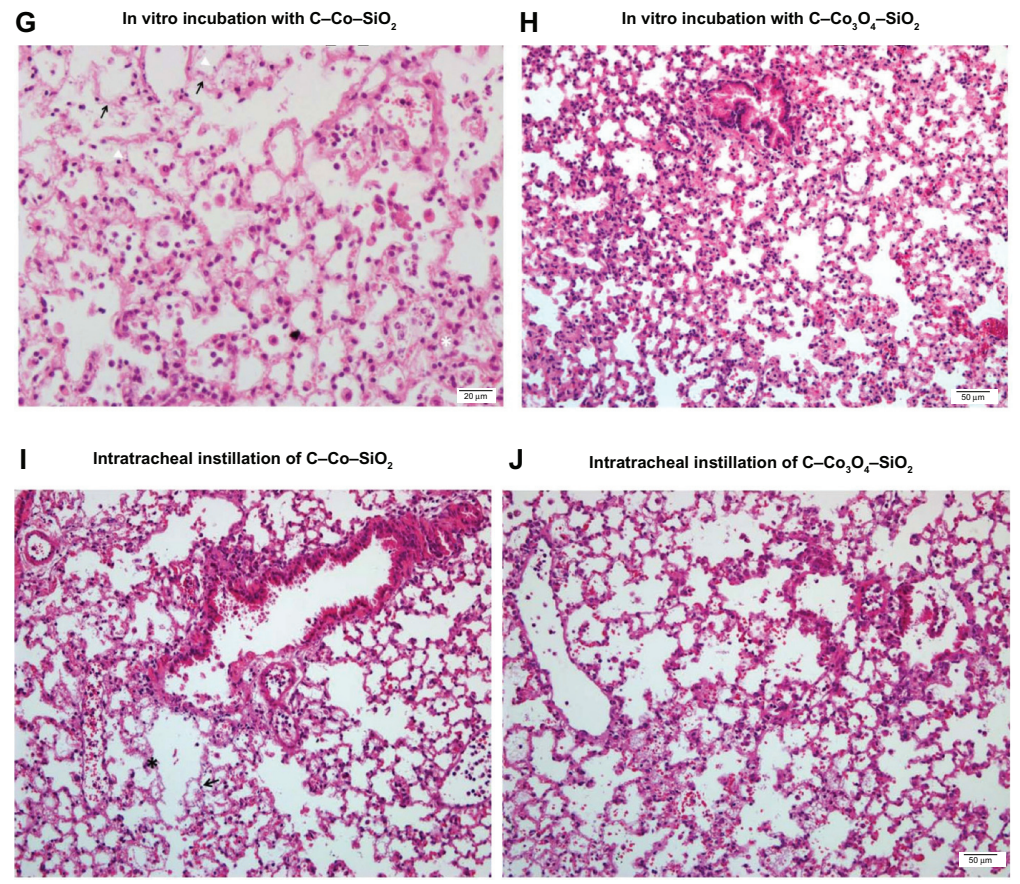

Figure 3 (A-J) Biocompatibility of $\mathrm{C}-\mathrm{Co}-\mathrm{SiO}_{2}$ and $\mathrm{C}-\mathrm{CO}_{3} \mathrm{O}_{4}-\mathrm{SiO}_{2}$ with lung respiration, adenosine triphosphate (ATP) content, caspase activity, and histology. (A and $\mathbf{B}$ ) Lung specimens were incubated in vitro at $37^{\circ} \mathrm{C}$ in oxygenated Krebs-Henseleit $(\mathrm{KH})$ buffer with and without $0.2 \mathrm{mg} / \mathrm{dL} \mathrm{C}-\mathrm{Co}_{-} \mathrm{SiO}{ }_{2}$ or $\mathrm{C}-\mathrm{Co}_{3} \mathrm{O}_{4}-\mathrm{SiO}_{2}$. A summary of the values of $k_{c}\left(\mu \mathrm{MO}_{2} /\right.$ minute/mg) for all experiments is shown in (A). The $P$-values are for comparisons with the untreated condition; " $n$ " is the number of independent measurements. Representative high-performance liquid chromatography (HPLC) runs at 4 hours are shown in (B). Briefly, lung specimens were incubated at $37^{\circ} \mathrm{C}$ with 37 Ac-DEVDAMC $\mu M$ for 20 minutes. The tissues were then disrupted by vigorous homogenization, and the supernatants were separated on HPLC and analyzed for the free AMC moiety. Ac-DEVD-AMC had a retention time, $R_{t}$, of $\sim 4.5$ minutes (insert) and AMC of $\sim 12.7$ minutes (running solvents, $\mathrm{CH}_{3} \mathrm{CN}_{2} \mathrm{dH}_{2} \mathrm{O}$ I:3). $(\mathbf{C}-\mathbf{F})$ Lung specimens were collected 60 minutes after intratracheal instillation of $10 \mathrm{mg} \mathrm{C}-\mathrm{Co}_{-} \mathrm{SiO}_{2}, 10 \mathrm{mg} \mathrm{C}-\mathrm{Co}_{3} \mathrm{O}_{4}-\mathrm{SiO}_{2}$, or $150 \mu \mathrm{L} 0.9 \% \mathrm{NaCl}$. The samples were then incubated in vitro at $37^{\circ} \mathrm{C}$ in oxygenated $\mathrm{KH}$ buffer. Cellular respiration and caspase activity were measured as a function of time. Representative $\mathrm{O}_{2}$ runs are show in (C and $\left.\mathbf{D}\right)$; the values of $k_{c}\left(\mu M \mathrm{O}_{2} / \mathrm{minute} / \mathrm{mg}\right)$ are shown at the bottom of each run. Representative HPLC runs of the samples 4 hours after incubation of the specimen with the nanoparticles are shown in (E). Ac-DEVDAMC had a retention time, $R_{t}$, of $\sim 2.5$ minutes (insert) and AMC of $\sim 4.7$ minutes (running solvents, methanol: $\mathrm{dH}_{2} \mathrm{O} \mathrm{I}: \mathrm{I}$ ). The AMC peak area is plotted as a function of time in (F). (G-J) Representative histology (hematoxylin and eosin) 4 hours after in vitro treatment $(\mathbf{G}$ and $\mathbf{H})$ and intratracheally treated $(\mathbf{I}$ and $\mathbf{J})$ lungs with $\mathbf{C}-\mathrm{Co}-\mathrm{SiO},(\mathbf{G}$ and I), or $\mathrm{C}-\mathrm{Co}_{3} \mathrm{O}_{4}-\mathrm{SiO}_{2}(\mathbf{H}$ and $\mathbf{J})$. The in vitro treatment with $\mathrm{C}-\mathrm{Co}-\mathrm{SiO}_{2}(\mathbf{G}, 40 \times$ ) revealed necrosis of the alveolar wall (arrow) and numerous apoptotic bodies (arrowheads), compared with a better-preserved area of the alveolar wall. Similar alterations were noted with $\mathrm{C}_{-}-\mathrm{Co}_{3} \mathrm{O}_{4}-\mathrm{SiO}_{2}(\mathbf{H}, 20 \times)$. The in vivo treatment with $\mathrm{C}-\mathrm{Co}-\mathrm{SiO}{ }_{2}$ revealed focal areas of alveolar wall damage and apoptotic bodies (arrows) adjacent to bronchioles. (I, 20x). The in vivo treatment with $\mathrm{C}_{-} \mathrm{Co}_{3} \mathrm{O}_{4}-\mathrm{SiO}_{2}$ revealed pulmonary tissue with preserved architecture. The alveolar wall is thinned, and there is vacuolization of pneumocytes and endothelial cells, with loss of definite cell outlines (J, 20x). 
A

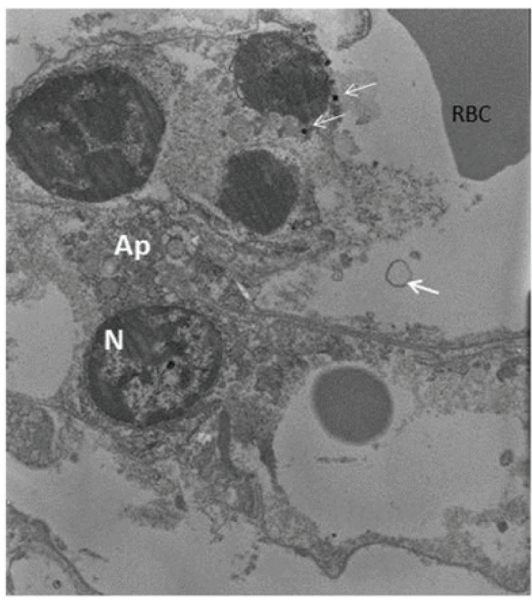

C
B

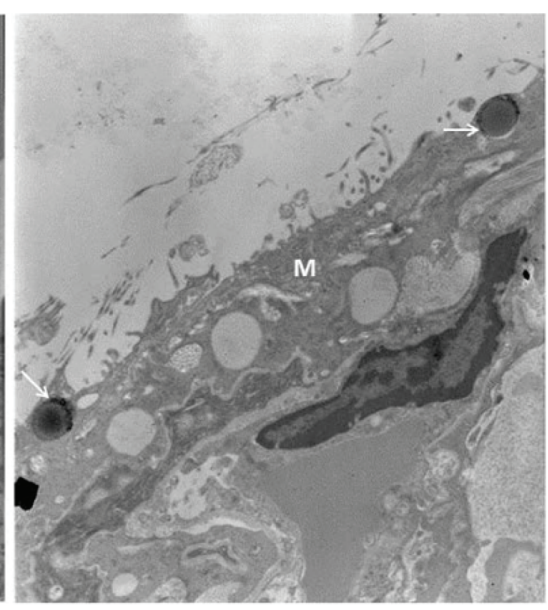

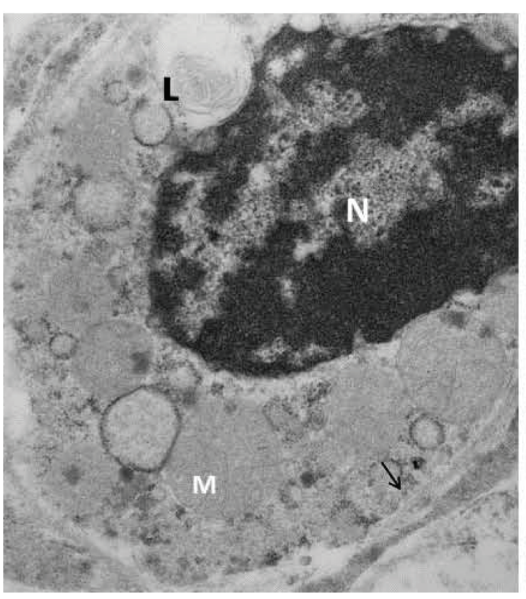

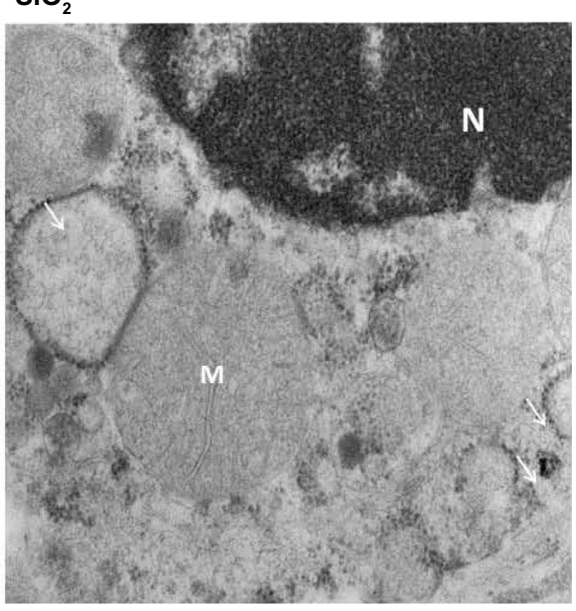

D

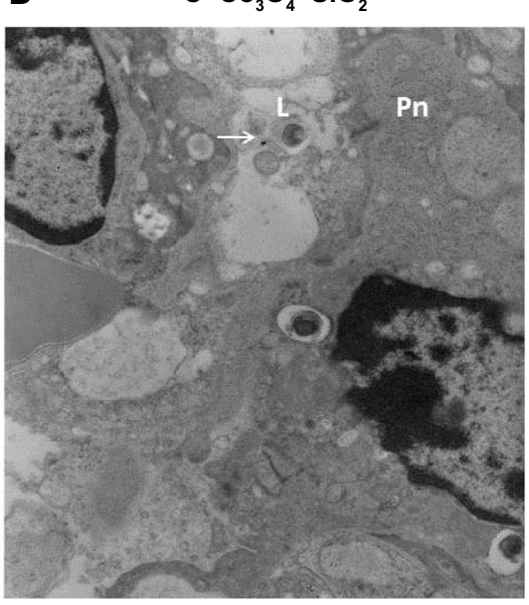

Figure 4 (A-D) Transmission electron microscopy images of lung specimens incubated in vitro at $37^{\circ} \mathrm{C}$ with and without $200 \mu \mathrm{g} / \mathrm{mL}$ nanoparticles for 5 hours. (A) $\mathrm{C}^{-S i O_{2}-}$ etched specimen, showing apoptotic cell (Ap) with fragmented nucleus $(\mathrm{N})$ and plasma membrane (arrows). Note electron-dense intracytoplasmic particles (thin arrows), magnification 700,000x. (B) $\mathrm{C}_{-} \mathrm{SiO}_{2}$-treated specimen, showing mesothelial cell (M) with cytoplasmic electron-dense particles centered around lysozymes (arrows), magnification 700,000×. (C) C-Co-SiO -treated specimen, showing type II pneumocyte (Pn) with a lamellar body (L), mega-mitochondria (m) and electron-dense cytoplasmic particles (arrows), magnifications: left 180,000x, right 350,000x. (D) $\mathrm{C}-\mathrm{Co}_{3} \mathrm{O}_{4}-\mathrm{SiO}_{2}$-treated specimen, showing type II pneumatocyte (Pn) with electron-dense particles (arrow) within a vacuole adjacent to a lamellar body (L), magnification $980,000 \times$.

Abbreviation: RBC, red blood cell.

\section{Discussion}

Lung toxicities of the following nanoparticles were studied: carbon (C) nanoparticles (labeled as: $\mathrm{C}-\mathrm{SiO}_{2}$-etched), carbon-silica (core-shell) nanoparticles (labeled as: $\mathrm{C}-\mathrm{SiO}_{2}$ ), carbon-cobalt-silica (core-shell-shell) nanoparticles (labeled as: $\mathrm{C}-\mathrm{Co}-\mathrm{SiO}_{2}$ ); and carbon-cobalt oxide-silica (core-shellshell) nanoparticles (labeled as: $\mathrm{C}-\mathrm{Co}_{3} \mathrm{O}_{4}-\mathrm{SiO}_{2}$ ). These and related nanoparticles have potential biological applications due to the unique magnetic properties of cobalt, the photothermal heating properties of carbon for thermotherapy of tumor tissue using near-infrared light, and the biocompatibility and ease of surface modification of silica with various bioactive functional groups. The toxicities of such nanoparticles, however, have not been adequately explored.
The primary aim of this work, thus, was to investigate the biocompatibility of these nanoparticles with pneumatocyte respiration (mitochondrial $\mathrm{O}_{2}$ consumption), especially since inhalation is a common way of exposure to these types of materials, which are increasingly being investigated and commercialized. The term "pneumatocyte respiration" implies delivery of $\mathrm{O}_{2}$ and metabolic fuels to the mitochondria, oxidation of reduced metabolic fuels with passage of electrons to $\mathrm{O}_{2}$, and synthesis of ATP. Impaired respiration thus entails an interference with any of these processes.

Lung tissue $\mathrm{O}_{2}$ consumption was measured with the aid of the phosphorescence oxygen analyzer using $\mathrm{Pd}(\mathrm{II})$-mesotetra-(4-sulfonatophenyl)-tetrabenzoporphyrin as a probing phosphor. This detection is based on the principle that $\mathrm{O}_{2}$ 


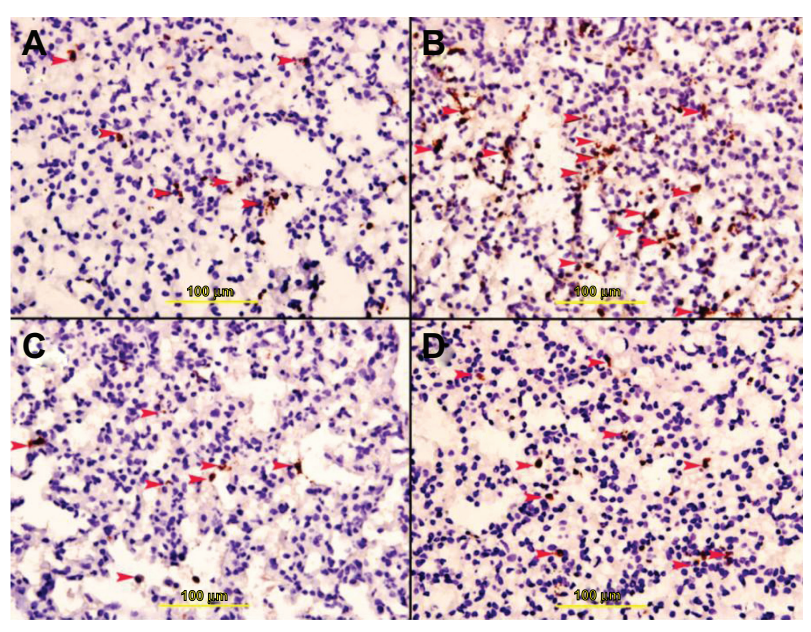

Figure 5 (A-D) Caspase-3 staining. Lung specimens were incubated in vitro at $37^{\circ} \mathrm{C}$ with and without $0.2 \mathrm{mg} / \mathrm{mL}$ core-shell nanomaterials composed of carbon, cobalt, and silica for 5 hours. The samples were then rinsed with Krebs-Henseleit buffer and stained with anti-cleaved caspase-3 antibody. (A) Specimen treated with $\mathrm{C}-\mathrm{SiO}_{2}$-etched nanoparticles showing apoptotic cells with brown granular cytoplasm (arrowheads); (B) specimen treated with $\mathrm{C}-\mathrm{SiO}_{2}$ nanoparticles showing apoptotic cells (arrowheads); (C) samples treated with $\mathrm{C}-\mathrm{Co}-\mathrm{SiO}_{2}$, showing apoptotic cells (arrowheads); and (D) specimen treated with $\mathrm{C}-\mathrm{Co}-\mathrm{SiO}_{2}$ nanoparticles showing apoptotic cells (arrowheads).

quenches the phosphorescence of the Pd(II)-based phosphor, ie, the phosphorescence intensity is inversely related to $\mathrm{O}_{2}$ concentration. ${ }^{24}$ The results show reasonable in vitro and in vivo biocompatibility of $\mathrm{C}-\mathrm{SiO}_{2}$-etched and $\mathrm{C}-\mathrm{SiO}_{2}$ nanoparticles with pneumatocyte respiration (Figures 1 and 2). Pneumatocyte bioenergetics, on the other hand, is significantly altered in the presence of $\mathrm{C}-\mathrm{Co}-\mathrm{SiO}_{2}$ or $\mathrm{C}-\mathrm{Co}_{3} \mathrm{O}_{4}-\mathrm{SiO}_{2}$, consistent with the known toxicity of cobalt toward mitochondrial respiration. ${ }^{27,28}$

The study also addressed lung tissue caspase activity of the nanoparticles investigated here. Caspase activity was determined by measuring the fluorescent moiety (ie, AMC) formed via a caspase dependent process from Ac-DEVDAMC. Cobalt and carbon are known to potently target the mitochondria, causing loss of mitochondrial respiration and potential $\left(\Delta \psi_{\mathrm{m}}\right)$ and release of apoptotic factors (eg, apoptosis-inducing factor). ${ }^{9}$ This known toxicity was most likely the reason behind the increased caspase activity in the specimens treated with $\mathrm{C}-\mathrm{SiO}_{2}$-etched nanoparticles (Figure $1 \mathrm{C}$ ) and $\mathrm{C}-\mathrm{Co}-\mathrm{SiO}_{2}$ nanoparticles (Figure 3B, $\mathrm{E}$, and $\mathrm{F}$ ). On the other hand, pneumatocyte respiration remained preserved in specimens treated with $\mathrm{C}-\mathrm{SiO}_{2}-$ etched nanoparticles, despite increased caspase activity in them (Figure 1C). Therefore, monitoring both biomarkers (respiration and caspase activity) is necessary for reliable assessments of cytotoxicity.

Structural alterations were seen in specimens treated with $\mathrm{C}-\mathrm{SiO}_{2}$-etched and $\mathrm{C}-\mathrm{Co}-\mathrm{SiO}_{2}$ nanoparticles, especially in vitro. The structural alterations included focal areas of necrosis, apoptotic cells, and swollen and mega-mitochondria (Figures 1, 3, and 4).

The observed impaired respiration and induction of caspases by $\mathrm{C}-\mathrm{Co}-\mathrm{SiO}_{2}$ and $\mathrm{C}-\mathrm{Co}_{3} \mathrm{O}_{4}-\mathrm{SiO}_{2}$ nanoparticles (Figures 3 and 5) are consistent with the known toxicities of cobalt. ${ }^{27,28}$ Activated caspases permeabilize the mitochondria and disrupt their function and structure. The involvement of mitochondria in apoptosis justifies monitoring respiration for a better assessment of cellular toxicities. ${ }^{21,29}$ It is worth emphasizing that uncoupling oxidative phosphorylation is a common mitochondrial toxicity, which produces increased rate of respiration and decreased cellular ATP (as noted in the specimens treated with the $\mathrm{C}-\mathrm{Co}_{3} \mathrm{O}_{4}-\mathrm{SiO}_{2}$ nanoparticles Table $\mathrm{S} 1$ in Supplementary materials).

The caspase activity data can be correlated with the morphological changes. For instance, the carbon-silica coreshell $\left(\mathrm{C}-\mathrm{SiO}_{2}\right)$ nanoparticles resulted in insignificant caspase activity with well-preserved lung structure in the specimens (Figure 2 and Figure S5 in Supplementary materials). $\mathrm{C}-\mathrm{SiO}_{2}$-etched (the carbon-silica core-shell after removal of their silica shell) nanoparticles, on the other hand, produced increased caspase activity with structural alternations on the specimens after 6 hours (Figure 1 and Figure S4 in Supplementary materials). Thus, the silica shells present in $\mathrm{C}-\mathrm{SiO}_{2}$ nanoparticles must have made these nanoparticles biocompatible with murine lung by ameliorating any possible toxicity associated with carbon.

The caspase activity data also demonstrate that the toxicity of cobalt-containing nanoparticles may hinge on the cobalt phase. Whereas the $\mathrm{C}-\mathrm{Co}_{3} \mathrm{O}_{4}-\mathrm{SiO}_{2}$ sample, in which the cobalt is present as an oxide, exhibited less caspase activity, the $\mathrm{C}-\mathrm{Co}-\mathrm{SiO}_{2}$ sample, where the cobalt is present in a zero-valence state, shows much more caspase activity (Figure 3B, E, and F). Therefore, for in vivo applications, the cobalt oxide $\left(\mathrm{Co}_{3} \mathrm{O}_{4}\right)$ phase is relatively less toxic and thus more preferable than the zero-valent $\operatorname{Co}(0)$ phase.

These results were corroborated by elemental analysis of cobalt ions that could possibly leach from the nanoparticles and make their way into the solution and contact the cells. By using ultraviolet-visible spectroscopy (see Materials and Methods for the detailed experimental procedures and Figures S6-S8 in Supplementary Information section for the results), the mol of cobalt species. For TA present in the solution was determined. The results (Figures S6-S8) indicated that the amount of cobalt leached from the nanoparticles containing metallic cobalt, ie, $\mathrm{C}-\mathrm{Co}-\mathrm{SiO}_{2}$, was about 2.4 times higher than from those containing cobalt oxide, or cobalt in the form 
of cobalt(II), ie, $\mathrm{C}-\mathrm{Co}_{3} \mathrm{O}_{4}-\mathrm{SiO}_{2}$. This result is consistent with the higher toxicity exhibited by $\mathrm{C}-\mathrm{Co}-\mathrm{SiO}_{2}$ compared with $\mathrm{C}-\mathrm{Co}_{3} \mathrm{O}_{4}-\mathrm{SiO}_{2}$. In other words, the fact that $\mathrm{C}-\mathrm{Co}-\mathrm{SiO}_{2}$ nanoparticles release more cobalt into the solution might be responsible for the material's higher toxicity compared with $\mathrm{C}-\mathrm{Co}_{3} \mathrm{O}_{4}-\mathrm{SiO}_{2}$ nanoparticles. This also implies that the $\mathrm{Co}_{3} \mathrm{O}_{4}$ phase might be more desirable than the Co phase for biological applications.

These results are both similar to and different from the observations made and the results reported by Wang et $\mathrm{al}^{30}$ on different but related metal oxide-based nanomaterials, specifically cuprous oxide nanoparticles (CONPs). Based on TEM studies, Wang et al showed that CONPs enter mitochondria, damage cell membranes, and induce apoptosis. The CONPs were also implicated to form reactive oxygen species and initiate lipid peroxidation of the liposomal membrane, which in turn affect many cellsignaling pathways and influence vital movements of cells. The authors also demonstrated that low concentrations of CONPs could selectively kill tumor cells, indicating their potential as nanomedicines for cancer treatment. By using flow cytometry, the authors further studied the mechanism by which CONPs cause cytotoxicity and cell death. Based on apoptosis and necrosis discrimination assays, the authors showed that CONPs exhibit dose-dependent necrosis and apoptosis in HeLa cells but not in embryonic fibroblast cells. This result highlighted CONPs' selective antitumor properties and potential uses as nanomedicine. In addition to these studies, the authors investigated cellular respiration of cells in the presence of CONPs. Their results indicated that the protein complexes responsible for electron transport chain or respiration in the cells contained cuprous ions in the active centers. Based on this result, they concluded that the CONPs release cuprous ions, which complex with proteins and thereby affect the electron transfer process in the respiratory chain, causing tumor cells to lack energy and start the apoptotic process. Hence, the results presented by Wang et $\mathrm{al}^{30}$ support why our $\mathrm{C}-\mathrm{Co}-\mathrm{SiO}_{2}$ nanoparticles, which released more cobalt ions in solution, exhibited higher toxicity than our $\mathrm{C}-\mathrm{Co}_{3} \mathrm{O}_{4}-\mathrm{SiO}_{2}$ nanoparticles, which produced much fewer cobalt ions in solution.

Intratracheal instillation is a well-recognized in vivo method of particle delivery. It offers direct administration of optimum dosage of drugs, avoiding upper-airway filtration. ${ }^{31}$ Furthermore, this alternative route to inhalation is relatively simple and requires fewer devices and less labor. In addition, the risk of accidental exposure during experimentation is lower with this method. Dosage, however, is an important variable. In previous studies in rats, 5-21 mg fixed dosages were employed. ${ }^{32,33} \mathrm{In}$ a study in mice, a dosage of $1-5 \mathrm{mg} / \mathrm{kg}$ was used. ${ }^{34}$ In another example, murine pulmonary toxicity of single-wall carbon nanotubes was evaluated using 0.1 and $0.5 \mathrm{mg}$ total dosage. ${ }^{35}$ In our case, each experiment was conducted by using 5 and $10 \mathrm{mg}$ intratracheal instillation dosage.

In summary, the results here show varying degrees of functional and structural toxicities of $\mathrm{C}-\mathrm{SiO}_{2}, \mathrm{C}-\mathrm{SiO}_{2}$-etched, $\mathrm{C}-\mathrm{Co}-\mathrm{SiO}_{2}$, and $\mathrm{C}-\mathrm{Co}_{3} \mathrm{O}_{4}-\mathrm{SiO}_{2}$ nanoparticles in murine lung. Our findings are consistent with the known inhibition of mitochondrial function by cobalt materials ${ }^{4,27,28}$ and induction of apoptosis by carbon nanotubes. ${ }^{36}$ Moreover, our results indicate that silica shells could help in improving the biocompatibility of inherently toxic nanoparticles. Finally, our findings suggest that cobalt oxide is a preferred phase over zero-valent $\operatorname{Co}(0)$ phase.

\section{Acknowledgments}

This work is funded by United Arab Emirates University. TA gratefully acknowledges the partial financial support by the US National Science Foundation for the NSF-American Competitiveness and Innovation Fellowships (NSF-ACIF) and the NSF Creativity Award in 2011. RS acknowledges the CAPES (Coordenação de Aperfeiçoamento de Pessoal de Nível Superior) in Brazil and the Fulbright Agency in USA for awarding him with fellowships and financial support for his graduate study. The technical assistance of Dr Sheela Benedict, Ms Manjusha Sudhadevi, and Mr Sarabjit Singh is greatly appreciated. The authors are very grateful to Professor Suhail Al-Salam for providing the caspase-3 staining figure.

\section{Disclosure}

The authors report no conflicts of interest in this work.

\section{References}

1. Liu Z, Liang XJ. Nano-carbons as theranostics. Theranostics. 2012;2: 235-237.

2. De La Zerda A, Zavaleta C, Keren S, et al. Carbon nanotubes as photoacoustic molecular imaging agents in living mice. Nat Nanotechnol. 2008;3:557-562.

3. Schipper ML, Nakayama-Ratchford N, Davis CR, et al. A pilot toxicology study of single-walled carbon nanotubes on a small sample of mice. Nat Nanotechnol. 2008;3:216-221.

4. Hirsch A. The era of carbon allotropes. Nat Mater. 2010;9:868-871.

5. Zhou FF, Wu SN, Wu BY, Chen WR, Xing D. Mitochondria-targeting single-walled carbon nanotubes for cancer photothermal therapy. Small. 2011;7:2727-2735.

6. Qhobosheane M, Santra S, Zhang P, Tan W. Biochemically functionalized silica nanoparticles. Analyst. 2001;126:1274-1278.

7. Yi DK, Selvan ST, Lee SS, Papaefthymiou GC, Kundaliya D, Ying JY. Silica-coated nanocomposites of magnetic nanoparticles and quantum dots. J Am Chem Soc. 2005;127:4990-4991. 
8. Frey NA, Peng S, Cheng K, Sun S. Magnetic nanoparticles: synthesis, functionalization, and applications in bioimaging and magnetic energy storage. Chem Soc Rev. 2009;38:2532-2542.

9. Karovic O, Tonazzini I, Rebola N, et al. Toxic effects of cobalt in primary cultures of mouse astrocytes: similarities with hypoxia and role of HIF-1 $\alpha$. Biochem Pharmacol. 2007;73:694-708.

10. Makhlouf SA. Magnetic properties of $\mathrm{Co}_{3} \mathrm{O}_{4}$ nanoparticles. J Magn Magn Mater. 2002;246:184-190.

11. Bouchard LS, Anwar MS, Liu GL, et al. Picomolar sensitivity MRI and photoacoustic imaging of cobalt nanoparticles. Proc Natl Acad Sci US A. 2009;106:4085-4089.

12. Choi J, Kim JC, Lee YB, Kim IS, Park YK, Hur NH. Fabrication of silica-coated magnetic nanoparticles with highly photoluminescent lanthanide probes. Chem Commun (Camb). 2007:1644-1646.

13. Kang K, Choi J, Nam JH, et al. Preparation and characterization of chemically functionalized silica-coated magnetic nanoparticles as a DNA separator. J Phys Chem B. 2009;113:536-543.

14. Asefa T, Tao Z. Biocompatibility of mesoporous silica nanoparticles. Chem Res Toxicol. 2012;25:2265-2284.

15. Al Samri MT, Al Shamsi M, Al-Salam S, et al. Measurement of oxygen consumption by murine tissues in vitro. J Pharmacol Toxicol Methods. 2010;63:196-204

16. Al-Jasmi F, Penefsky HS, Souid AK. The phosphorescence oxygen analyzer as a screening tool for disorders with impaired lymphocyte bioenergetics. Mol Genet Metab. 2011;104:529-536.

17. Shaban S, Marzouqi F, Al Mansouri A, Penefsky HS, Souid AK. Oxygen measurements via phosphorescence. Comput Methods Programs Biomed. 2010;100:265-268.

18. Souid AK, Tacka KA, Galvan KA, Penefsky HS. Immediate effects of anticancer drugs on mitochondrial oxygen consumption. Biochem Pharmacol. 2003;66:977-987.

19. Al Shamsi M, Al Samri MT, Al-Salam S, et al. Biocompatibility of calcined mesoporous silica particles with cellular bioenergetics in murine tissues. Chem Res Toxicol. 2010;23:1796-1805.

20. Green DR, Kroemer G. The pathophysiology of mitochondrial cell death. Science. 2004;305:626-629.

21. Hao Z, Duncan GS, Chang CC, et al. Specific ablation of the apoptotic functions of cytochrome c reveals a differential requirement of cytochrome $\mathrm{c}$ and Apaf-1 in apoptosis. Cell. 2005;121: 579-591.

22. Tao Z, Goodisman J, Penefsky HS, Souid AK. Caspase activation by anticancer drugs: the caspase storm. Mol Pharm. 2007;4:583-595.
23. Saffiotti U, Cefis F, Kolb LH. A method for the experimental induction of bronchogenic carcinoma. Cancer Res. 1968;28:104-124.

24. Lo LW, Koch CJ, Wilson DF. Calibration of oxygen-dependent quenching of the phosphorescence of Pd-meso-tetra(4-carboxyphenyl) porphine: a phosphor with general application for measuring oxygen concentration in biological systems. Anal Biochem. 1996;236:153-160.

25. Silva R, Al-Sharab J, Asefa T. Edge plane-rich nitrogen-doped carbon nanoneedles and efficient metal-free electrocatalysts. Angew Chem Int Ed Engl. 2012;51:7171-7175.

26. Silva R, Haraguchi SK, Muniz EC, Rubira AF. Applications of lignocellulosic fibers in polymer chemistry and in composites. Quim Nova. 2009;32:661-671.

27. Dingle JT, Heath JC, Webb M, Daniel M. The biological action of cobalt and other metals II. The mechanism of the respiratory inhibition produced by cobalt in mammalian tissues. Biochim Biophys Acta. 1962;65:34-46.

28. Wiberg GS, Munro IC, Morrison AB. Effect of cobalt ions on myocardial metabolism. Can J Biochem. 1967;47:1219-1223.

29. Wang C, Youle RJ. The role of mitochondria in apoptosis. Ann. Rev. Genetics. 2009;43:95-118.

30. Wang Y, Zi XY, Su J, et al. Cuprous oxide nanoparticles induce apoptosis of tumor cells. Int J Nanomedicine. 2012;7:2641-2652.

31. Driscoll KE, Costa DL, Hatch G, et al. Intratracheal instillation as an exposure technique for the evaluation of respiratory tract toxicity: uses and limitations. Toxicol Sci. 2000;55:24-35.

32. Wilfong ER, Lyles M, Rietcheck RL, et al. The acute and long-term effects of Middle East sand particles on the rat airway following a single intratracheal instillation. J Toxicol Environ Health A. 2011;74:1351-1365.

33. Sager TM, Kommineni C, Castranova V. Pulmonary response to intratracheal instillation of ultrafine versus fine titanium dioxide: role of particle surface area. Part Fibre Toxicol. 2008;5:17.

34. Warheit DB, Webb TR, Reed KL, Frerichs S, Sayes CM. Pulmonary toxicity study in rats with three forms of ultrafine- $\mathrm{TiO}_{2}$ particles: differential responses related to surface properties. Toxicology. 2007;230:90-104

35. Lam CW, James JT, McCluskey R, Hunter RL. Pulmonary toxicity of single-wall carbon nanotubes in mice 7 and 90 days after intratracheal instillation. Toxicol Sci. 2004;77:126-134.

36. Bottini M, Bruckner S, Nika K, et al. Multi-walled carbon nanotubes induce T lymphocyte apoptosis. Toxicol Lett. 2006;160:121-126. 


\section{Supplementary materials}

\section{Analysis of cobalt ions possibly leached from cobalt-based nanoparticles into solution}

Many metal ions are known to leach from their corresponding nanoparticles. Thus, we can expect that the cobalt ions in the cobalt-based nanomaterials could also leach and find their way into the solution. Furthermore, the amount of cobalt that could leach from the nanoparticles could vary from one type of nanoparticle to another. Most importantly, the leached metal ions may be responsible for the biological activities exhibited by the nanoparticles in solutions or for the different biological results we observed for the different nanoparticles we synthesized. Hence, the amount of soluble cobalt ions in solutions containing the cobalt-based nanoparticles was analyzed. This was achieved by using colorimetric analysis. ${ }^{1-3}$ Colorimetric assay was employed for analysis of Co species in the solution because it is very suitable and yet easy to use for the analysis of cobalt ions present in aqueous media (ie, cobalt ions leached into aqueous solution from the Co-based nanoparticles, in our case). Furthermore, interferences or cross-reaction are not expected to affect the analysis, because there is no other metallic element than cobalt in our case.

In a colorimetric analysis, the metal ions are quantified by using the Beer-Lambert law, which takes into account the relationships between the concentrations of optically active species of the metal ions with their absorbance. To successfully use the method, the metal ions should first be converted into optically active species if they are not

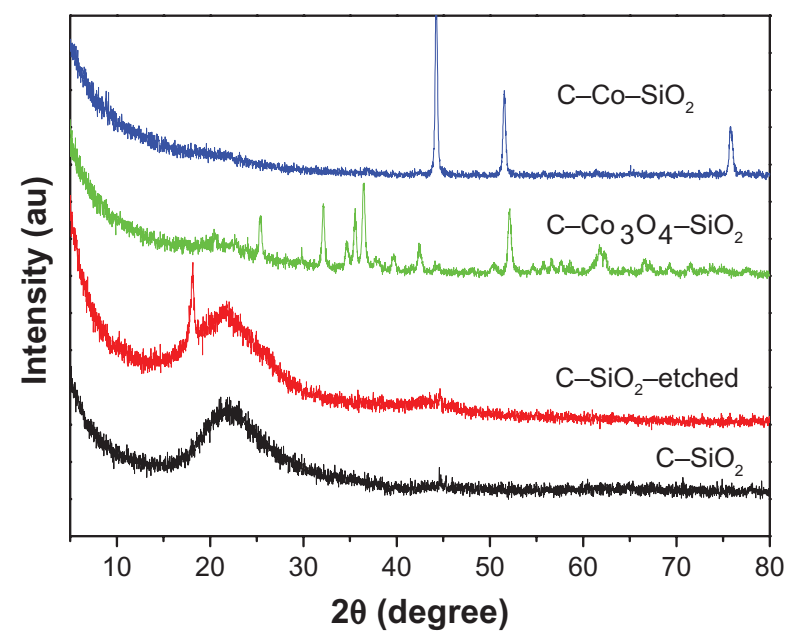

Figure SI Powder X-ray diffraction patterns of $\mathrm{C}-\mathrm{SiO}_{2}, \mathrm{C}-\mathrm{SiO}_{2}$-etched, $\mathrm{C}-\mathrm{Co}_{3} \mathrm{O}_{4}-$ $\mathrm{SiO}_{2}$, and $\mathrm{C}-\mathrm{Co}-\mathrm{SiO}_{2}$ nanoparticles investigated. optically active by themselves. This can be done by using ligands that form optically active metal-ligand complexes. In the case of the cobalt ions, this can easily be done by using ammonia, with which cobalt ions form stable and optically active hexaamminecobalt(III) complexes. Even if the ligand (ie, ammonia) is used in excess, the free ligand molecules in the solution do not affect the result because they do not absorb in the visible range of electromagnetic radiation. The quantification of the ions is then carried out by comparing the absorbance of the solution containing cobalt ions with a calibration curve generated using standard $\mathrm{Co}$ (III) ions with well-known concentrations (Figures S3 and S4).

\section{Experimental procedure for colorimetric determination of cobalt from nanoparticles studied}

First, $20 \mathrm{mg}$ of the samples $\left(\mathrm{C}-\mathrm{Co}-\mathrm{SiO}_{2}\right.$ or $\left.\mathrm{C}-\mathrm{Co}_{3} \mathrm{O}_{4}-\mathrm{SiO}_{2}\right)$ were dispersed in $200 \mu \mathrm{L}$ of distilled water. After keeping the solution for 24 hours, the particles were removed by centrifugation. The supernatant was used in the colorimetric determination of $\mathrm{Co}^{2+}$ by ultraviolet-visible spectroscopy. To perform this, $6 \mu \mathrm{L}$ of $\mathrm{NH}_{3}$ was added into the supernatant to form a $\left(\mathrm{Co}\left[\mathrm{NH}_{3}\right]_{6}\right)^{2+}$ complex. The $\mathrm{Co}^{2+}$ ions were then analyzed by using the absorption signal corresponding to $\left(\mathrm{Co}\left[\mathrm{NH}_{3}\right]_{6}\right)^{2+}$.

Figure S5 shows that the amount of cobalt leached from the sample containing metallic cobalt (ie, $\mathrm{C}-\mathrm{Co}-$

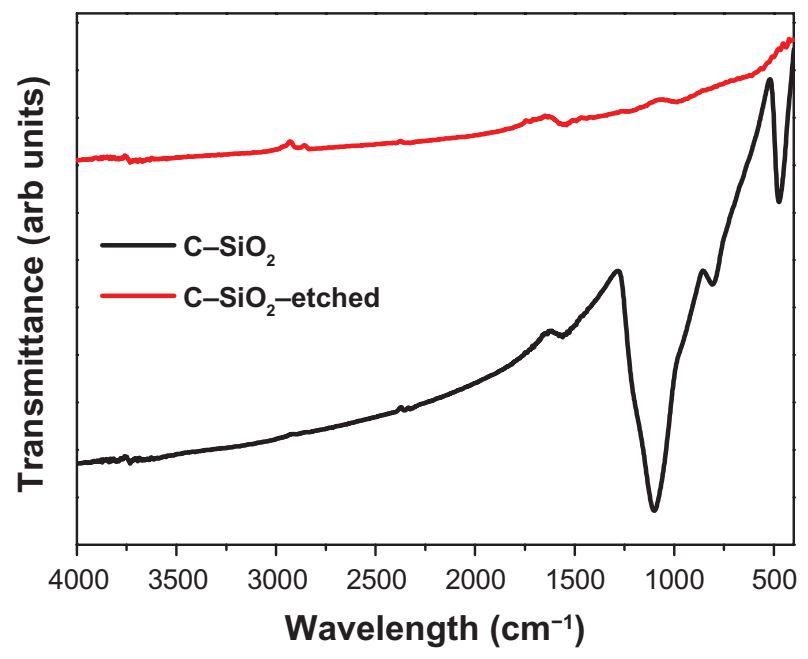

Figure S2 Fourier-transform infrared spectra of $\mathrm{C}-\mathrm{SiO}_{2}$ and $\mathrm{C}-\mathrm{SiO}_{2}$-etched nanoparticles.

Notes: The strong Si-O stretching band observed at around $1100 \mathrm{~cm}^{-1}$ in the $\mathrm{C}-\mathrm{SiO}_{2}$ sample is completely absent in the $\mathrm{C}-\mathrm{SiO}_{2}$-etched sample. This indicates that the silica shells around the $\mathrm{C}-\mathrm{SiO}_{2}$ core-shell nanoparticles were completely removed after treatment of these nanoparticles with dilute $\mathrm{NaOH}$ solution. 

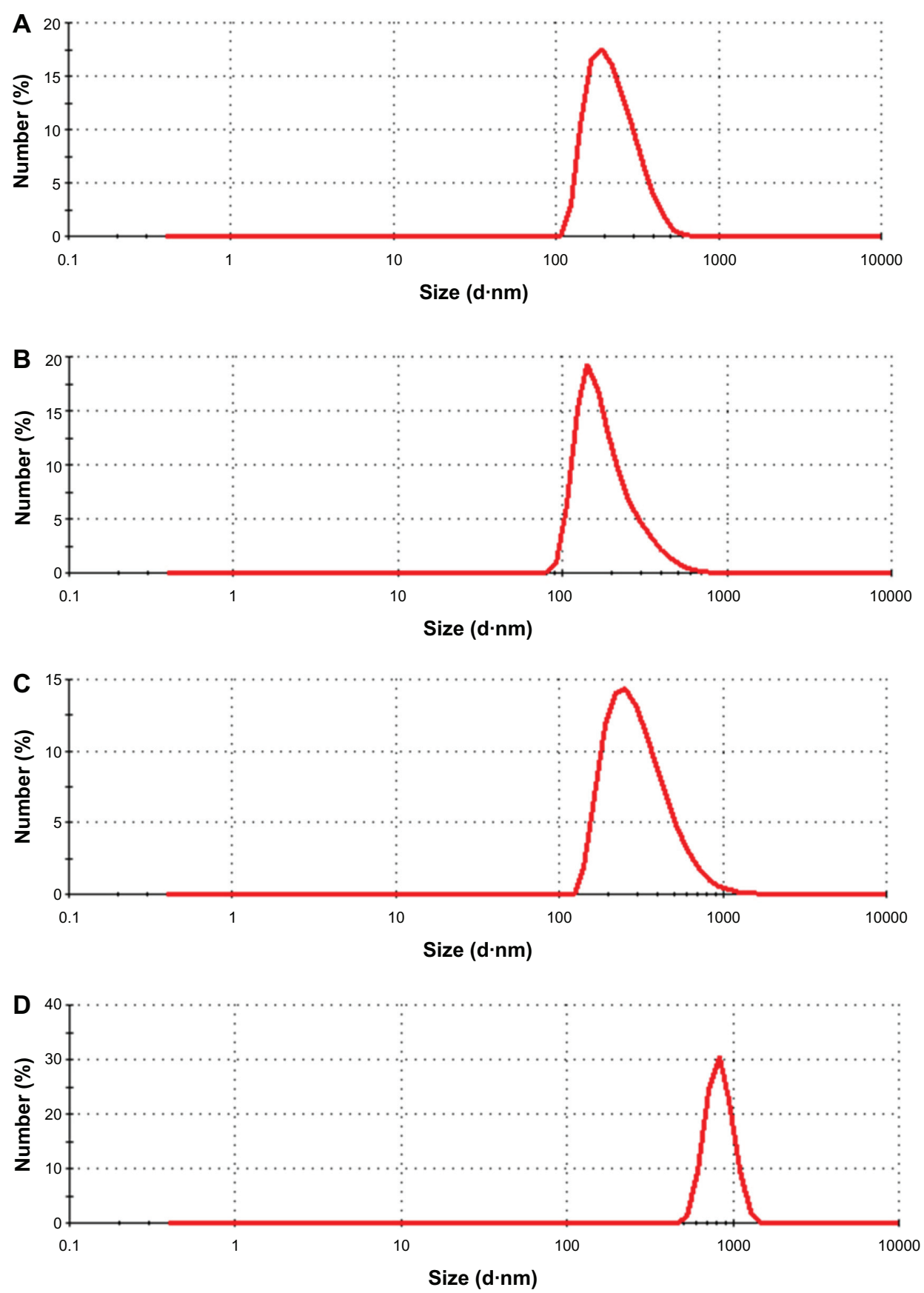

Figure S3 Size distribution of nanoparticles determined by dynamic light scattering for (A) $\mathrm{C}-\mathrm{SiO}_{2}$, (B) $\mathrm{C}-\mathrm{SiO}_{2}$-etched, (C) $\mathrm{C}_{-} \mathrm{Co}_{3} \mathrm{O}_{4}-\mathrm{SiO}_{2}$, and $(\mathbf{D}) \mathrm{C}-\mathrm{Co}-\mathrm{SiO}{ }_{2}$ nanoparticles. 


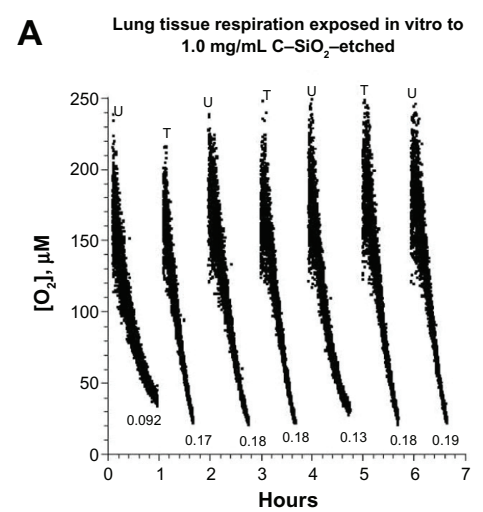

D Respiration following intratracheal installation

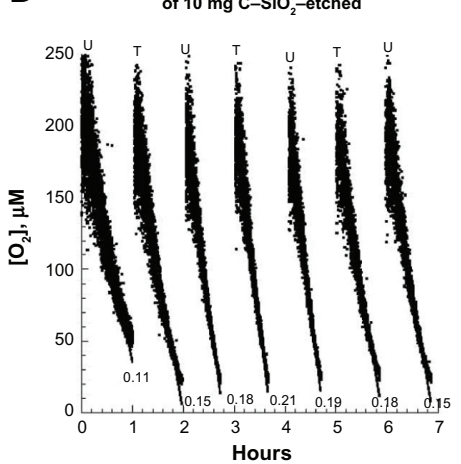

\section{B}

Lung tissue respiration and ATP content following in vitro incubation with and without $1.0 \mathrm{mg} / \mathrm{mL} \mathrm{C}-\mathrm{SiO}_{2}$-etched

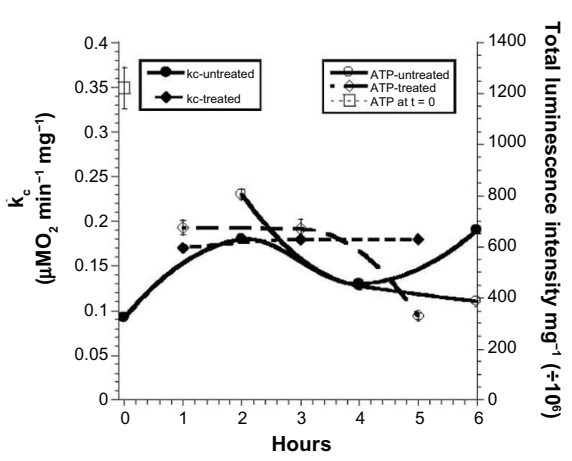

E

Respiration and ATP content following intratracheal

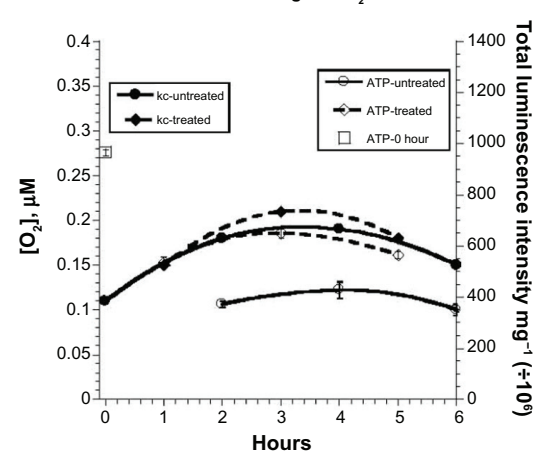

C In vitro incubation with $1.0 \mathrm{mg} / \mathrm{mL}$ C- $\mathrm{SiO}_{2}$-etched

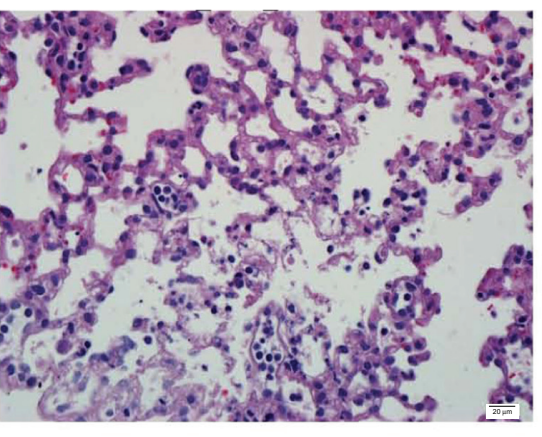

$\mathbf{F}$

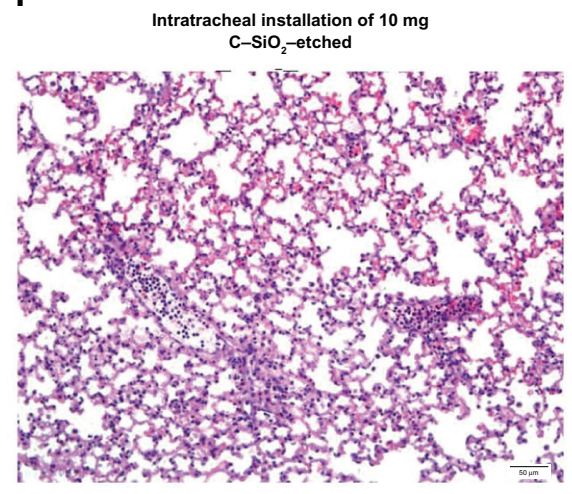

Figure S4 (A-F) Biocompatibility of $\mathrm{C}_{-}-\mathrm{SiO}_{2}$-etched nanoparticles with lung respiration, adenosine triphosphate (ATP) content, and histology. (A-C) Lung specimens were incubated in vitro at $37^{\circ} \mathrm{C}$ in oxygenated Krebs-Henseleit $(\mathrm{KH})$ buffer with and without $1.0 \mathrm{mg} / \mathrm{dL} \mathrm{C-SiO}$-etched nanoparticles. Cellular respiration, ATP content, and histology were then measured, as described in Figure I. Representative $\mathrm{O}_{2}$ runs are shown in $(\mathbf{A})$; rates of respiration $\left(k_{c}, \mu M O_{2} / \mathrm{minute} / \mathrm{mg}\right)$ are shown at the bottom of each run $\left(\mathrm{U}\right.$, untreated; $\mathrm{T}$, treated). The values of $k_{c}$ and ATP content are plotted as a function of $t$ in (B). Representative histology (hematoxylin and eosin, $\left.40 \times\right)$ at 4 hours (C) revealed foci of alveolar wall necrosis and apoptotic bodies. (D-F) Lung specimens were collected 60 minutes after intratracheal instillation of 10 mg C-SiO -etched nanoparticles or $150 \mu \mathrm{L} \mathrm{NaCl}$. The samples were then incubated in vitro at $37^{\circ} \mathrm{C}$ in oxygenated $\mathrm{KH}$ buffer. Cellular respiration (D and E) and ATP content (E) were measured as a function of time. Representative histology (hematoxylin and eosin, 40×) at 4 hours (F) revealed relatively preserved pulmonary architecture. 
Table SI Summary of the effects of studied nanoparticles on the measured biomarkers

\begin{tabular}{|c|c|c|c|c|}
\hline \multicolumn{5}{|l|}{ (A) } \\
\hline Biomarkers & Untreated & $\mathrm{C}-\mathrm{SiO}_{2}$-etched & $\begin{array}{l}\text { Ex vivo } \\
\text { incubation time }\end{array}$ & Dosing \\
\hline \multicolumn{5}{|c|}{ Intratracheal installation } \\
\hline$k_{c}(2$ mice/group $)$ & $\begin{array}{l}0.15 \pm 0.03 \\
n=8\end{array}$ & $\begin{array}{l}0.18 \pm 0.02 \\
\mathrm{n}=6 \\
P=0.282\end{array}$ & $\leq 7$ hours & $5 \mathrm{mg}$ \\
\hline \multirow[t]{2}{*}{ ATP (2 mice/group) } & $\begin{array}{l}88 \pm 27 \\
n=9\end{array}$ & $\begin{array}{l}\mathrm{l} 19 \pm 27 \\
\mathrm{n}=9 \\
P=0.200\end{array}$ & $1-6$ hours & $5 \mathrm{mg}$ \\
\hline & $\begin{array}{l}383 \pm 39 \\
n=3\end{array}$ & $\begin{array}{l}583 \pm 61 \\
\mathrm{n}=3 \\
P=0.100\end{array}$ & I-6 hours & $10 \mathrm{mg}$ \\
\hline $\begin{array}{l}\text { AMC peak area } \\
\text { (I mouse/group) }\end{array}$ & 3.0 & 4.9 ( $\uparrow$ I.6-fold) & At third hour & $5 \mathrm{mg}$ \\
\hline \multicolumn{5}{|l|}{ In vitro exposure } \\
\hline$k_{c}(\geq 3$ mice $)$ & $\begin{array}{l}0.19 \pm 0.05 \\
n=35\end{array}$ & $\begin{array}{l}0.19 \pm 0.04 \\
\mathrm{n}=11 \\
P=0.957\end{array}$ & $\leq 8$ hours & $0.2 \mathrm{mg} / \mathrm{mL}$ \\
\hline ATP (I mouse) & $\begin{array}{l}546 \pm 226 \\
n=3\end{array}$ & $\begin{array}{l}558 \pm 199 \\
\mathrm{n}=3 \\
P=1.00\end{array}$ & I-6 hours & $1.0 \mathrm{mg} / \mathrm{mL}$ \\
\hline $\begin{array}{l}\text { AMC peak area } \\
\text { (I mouse) }\end{array}$ & $\begin{array}{l}4.2 \\
14.7 \\
\end{array}$ & $\begin{array}{l}16.6 \text { ( } \uparrow 4 \text {-fold }) \\
41.5 \text { ( } \uparrow \text { I0-fold })\end{array}$ & $\begin{array}{l}\text { At fourth hour } \\
\text { At fifth hour }\end{array}$ & $0.2 \mathrm{mg} / \mathrm{mL}$ \\
\hline \multicolumn{5}{|l|}{ (B) } \\
\hline Biomarkers & Untreated & $\mathrm{C}-\mathrm{SiO}_{2}$ & $\begin{array}{l}\text { Ex vivo } \\
\text { incubation time }\end{array}$ & Dosing \\
\hline \multicolumn{5}{|c|}{ Intratracheal installation } \\
\hline$k_{c}(2$ mice/group $)$ & $\begin{array}{l}0.16 \pm 0.04 \\
n=8\end{array}$ & $\begin{array}{l}0.19 \pm 0.05 \\
\mathrm{n}=6 \\
P=0.345\end{array}$ & $\leq 8$ hours & $5 \mathrm{mg}$ \\
\hline ATP (2 mice/group) & $\begin{array}{l}251 \pm 62 \\
n=6\end{array}$ & $\begin{array}{l}284 \pm 113 \\
n=6 \\
P=0.699\end{array}$ & I-6 hours & $5 \mathrm{mg}$ \\
\hline (2 mice/group) & $\begin{array}{l}4.4 \pm 3.6 \\
n=6\end{array}$ & $\begin{array}{l}3.0 \pm 2.6 \\
\mathrm{n}=6 \\
P=0.240\end{array}$ & At 0,3 , and 6 hours & $5 \mathrm{mg}$ \\
\hline \multicolumn{5}{|l|}{ In vitro exposure } \\
\hline$k_{c}(\geq 3$ mice $)$ & $\begin{array}{l}0.19 \pm 0.05 \\
n=35\end{array}$ & $\begin{array}{l}0.20 \pm 0.03 \\
\mathrm{n}=7 \\
P=0.463\end{array}$ & $<8$ hours & $0.2 \mathrm{mg} / \mathrm{mL}$ \\
\hline ATP (I mouse) & $\begin{array}{l}2659 \pm 531 \\
n=3\end{array}$ & $\begin{array}{l}2726 \pm 1212 \\
\mathrm{n}=3 \\
P=1.00\end{array}$ & $1-6$ hours & $1.0 \mathrm{mg} / \mathrm{mL}$ \\
\hline $\begin{array}{l}\text { AMC peak area } \\
\text { (I mouse) }\end{array}$ & $\begin{array}{l}14.2 \\
14.7\end{array}$ & $\begin{array}{l}19.1 \text { ( } \uparrow \text { I.4-fold }) \\
24.7 \text { ( } \uparrow \text { I.7-fold })\end{array}$ & $\begin{array}{l}\text { At } 3 \text { hours } \\
\text { At } 5 \text { hours }\end{array}$ & $0.2 \mathrm{mg} / \mathrm{mL}$ \\
\hline
\end{tabular}


Table SI (Continued)

(C)

\begin{tabular}{|c|c|c|c|c|}
\hline Biomarkers & Untreated & $\mathrm{C}-\mathrm{Co}-\mathrm{SiO}_{2}$ & $\begin{array}{l}\text { Ex vivo } \\
\text { incubation time }\end{array}$ & Dosing \\
\hline \multicolumn{5}{|c|}{ Intratracheal installation } \\
\hline$k_{c}(2$ mice/group $)$ & $\begin{array}{l}0.15 \pm 0.03 \\
n=16\end{array}$ & $\begin{array}{l}0.18 \pm 0.04 \\
\mathrm{n}=6 \\
P=0.178\end{array}$ & $\leq 4$ hours & $10 \mathrm{mg}$ \\
\hline ATP (2 mice/group) & $\begin{array}{l}2659 \pm 51 \\
n=3\end{array}$ & $\begin{array}{l}2244 \pm 1217 \\
n=4 \\
P=0.629\end{array}$ & $\leq 4$ hours & $10 \mathrm{mg}$ \\
\hline $\begin{array}{l}\text { AMC peak area } \\
\text { ( } 2 \text { mice/group) }\end{array}$ & 0.9 & 14.7 (个16-fold) & At 6 hours & $10 \mathrm{mg}$ \\
\hline \multicolumn{5}{|l|}{ In vitro exposure } \\
\hline$k_{c}(\geq 3$ mice $)$ & $\begin{array}{l}0.19 \pm 0.05 \\
n=35\end{array}$ & $\begin{array}{l}0.13 \pm 0.05 \\
\mathrm{n}=7 \\
P=0.014\end{array}$ & $<8$ hours & $0.2 \mathrm{mg} / \mathrm{mL}$ \\
\hline $\begin{array}{l}\text { AMC peak area } \\
\text { (I mouse) }\end{array}$ & 7.9 & 47.8 ( $\uparrow$ 6-fold) & At 4 hours & $0.2 \mathrm{mg} / \mathrm{mL}$ \\
\hline \multicolumn{5}{|l|}{ (D) } \\
\hline Biomarkers & Untreated & $\mathrm{C}-\mathrm{Co}_{3} \mathrm{O}_{4}-\mathrm{SiO}_{2}$ & $\begin{array}{l}\text { Ex vivo } \\
\text { incubation time }\end{array}$ & Dosing \\
\hline \multicolumn{5}{|c|}{ Intratracheal installation } \\
\hline$k_{c}(2$ mice/group $)$ & $\begin{array}{l}0.15 \pm 0.03 \\
n=16\end{array}$ & $\begin{array}{l}0.21 \pm 0.05 \\
\mathrm{n}=7 \\
P=0.009\end{array}$ & $\leq 6$ hours & $10 \mathrm{mg}$ \\
\hline ATP (2 mice/group) & $\begin{array}{l}2659 \pm 5 l \\
n=3\end{array}$ & $\begin{array}{l}1045 \pm 242 \\
\mathrm{n}=6 \\
P=0.024\end{array}$ & $\leq 6$ hours & $10 \mathrm{mg}$ \\
\hline $\begin{array}{l}\text { AMC peak area } \\
\text { ( } 2 \text { mice/group) } \\
\text { In vitro exposure }\end{array}$ & 0.9 & 0.8 & At 6 hours & $10 \mathrm{mg}$ \\
\hline$k_{c}(\geq 3$ mice $)$ & $\begin{array}{l}0.19 \pm 0.05 \\
n=35\end{array}$ & $\begin{array}{l}0.22 \pm 0.04 \\
\mathrm{n}=7 \\
P=0.198\end{array}$ & $<8$ hours & $0.2 \mathrm{mg} / \mathrm{mL}$ \\
\hline $\begin{array}{l}\text { AMC peak area } \\
\text { (I mouse) }\end{array}$ & 7.9 & 22.9 ( $\uparrow 3$-fold $)$ & At 4 hours & $0.2 \mathrm{mg} / \mathrm{mL}$ \\
\hline
\end{tabular}

Notes: The values are listed as means \pm standard deviation; Rate of cellular respiration, $k_{c}$ is expressed as $\mu M O_{2} /$ minute/mg. Cellular adenosine triphosphate (ATP) content (measured hourly from I to 6 hours in triplicates) is expressed as total luminescence intensity $\mathrm{mg} / 10^{6}$. AMC peak area (measured at 0,3 , and 6 hours) is expressed in arbitrary unit $\mathrm{mg} / 10^{6}$. The differences in the luminescence intensity between experiments are due to aging of the reagents.

Abbreviation: $n$, number of runs. 
A Lung tissue respiration exposed in vitro to

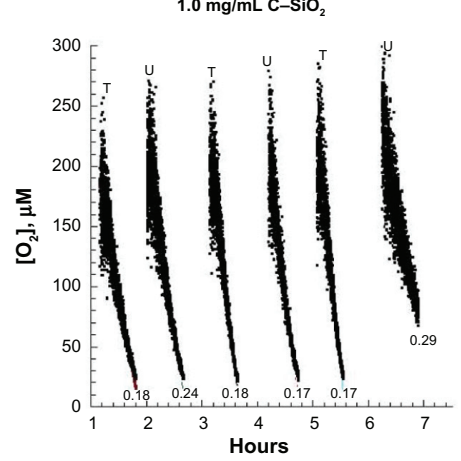

D Respiration following intratracheal installation of $5 \mathrm{mg} / \mathrm{kg} \mathrm{mg} \mathrm{C}-\mathrm{SiO}_{2}$

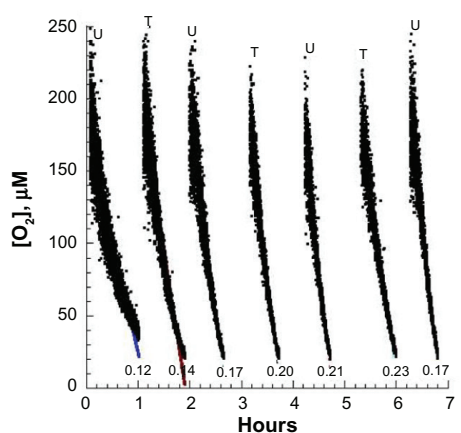

B Lung tissue respiration and ATP content following in vitro incubation with and without $1.0 \mathrm{mg} / \mathrm{mL} \mathrm{C}-\mathrm{SiO}_{2}$

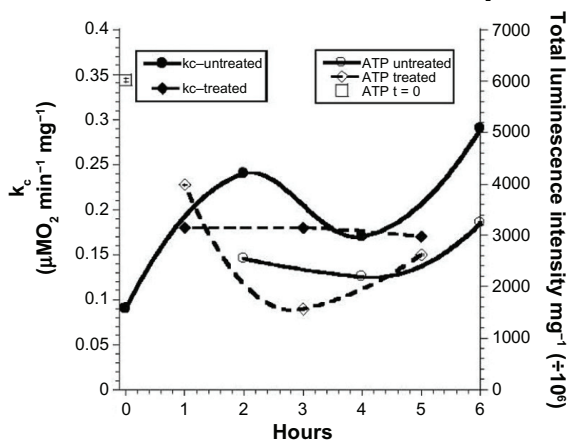

E

Respiration and ATP content following

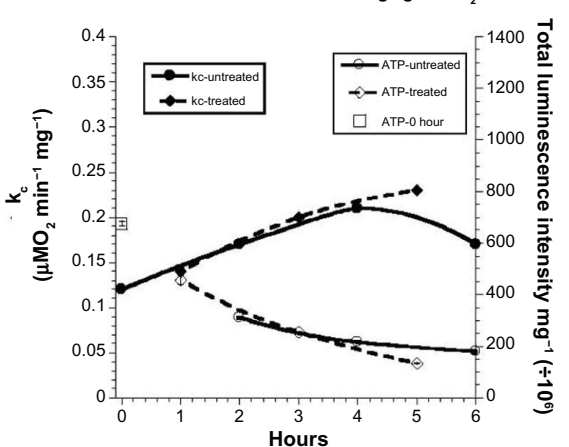

C In vitro incubation with $1.0 \mathrm{mg} / \mathrm{mL}$ $\mathrm{C}-\mathrm{SiO}_{2}$

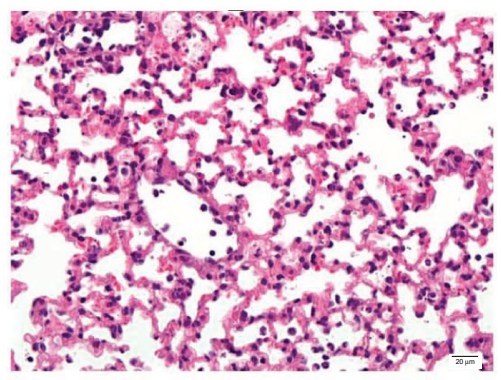

F Caspase activity following intratracheal installation

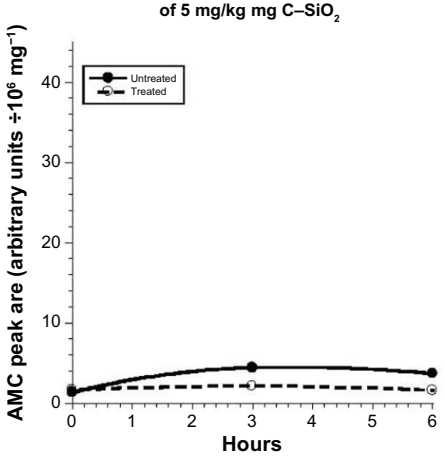

Figure S5 (A-F) Biocompatibility of $\mathrm{C}-\mathrm{SiO}_{2}$ with lung respiration, adenosine triphosphate (ATP) content, caspase activity, and histology. (A-C) Lung specimens were incubated in vitro at $37^{\circ} \mathrm{C}$ in oxygenated Krebs-Henseleit $(\mathrm{KH})$ buffer with and without $1.0 \mathrm{mg} / \mathrm{dL} \mathrm{C-SiO}{ }_{2}$. Cellular respiration $(\mathbf{A}$ and $\mathbf{B})$ and ATP content $(\mathbf{B})$ were then measured as a function of time, as described on Figure 2. Representative $\mathrm{O}_{2}$ runs are shown in $\mathbf{A}$; the values of $k_{c}\left(\mu M \mathrm{O}_{2} / \mathrm{minute} / \mathrm{mg}\right.$ ) are shown at the bottom of each run $(\mathrm{U}$, untreated; $\mathrm{T}$, treated). Representative histology (hematoxylin and eosin, 40x) at 4 hours (C) revealed preserved pulmonary architecture. (D-F) Lung specimens were collected 60 minutes after intratracheal instillation of $5 \mathrm{mg} / \mathrm{kg} \mathrm{C}-\mathrm{SiO}_{2}$ or $150 \mu \mathrm{L} 0.9 \% \mathrm{NaCl}$. The samples were then incubated in vitro at $37^{\circ} \mathrm{C}$ in oxygenated $\mathrm{KH}$ buffer. Cellular respiration (D and $\mathbf{E})$, ATP content $(\mathbf{E})$, and caspase activity $(\mathbf{F})$ were then measured as a function of time.

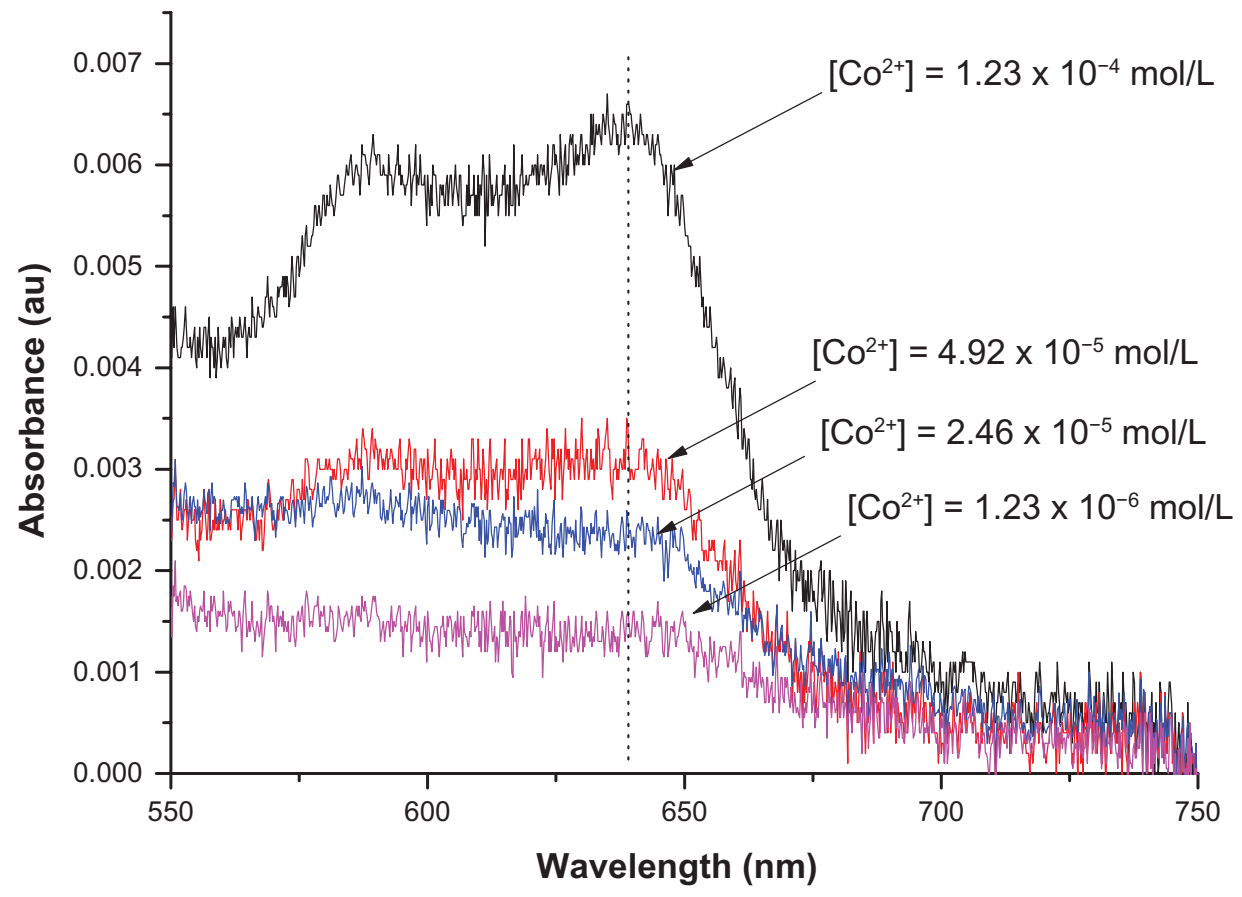

Figure S6 Ultraviolet-visible spectra of different known concentrations of aqueous of $\mathrm{Co}^{2+}$ ions. 


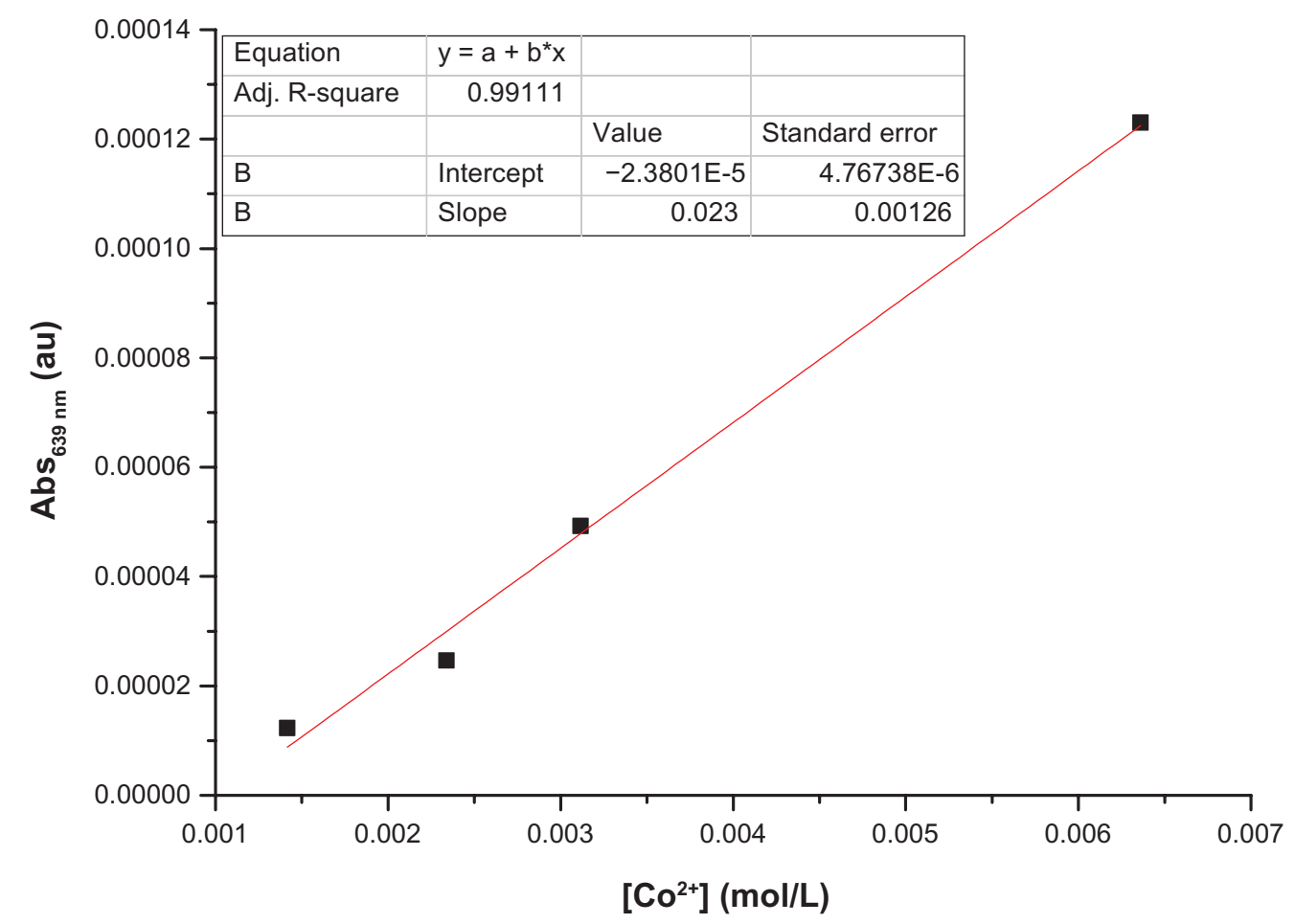

Figure S7 Calibration curve used for the colorimetric determination of $\mathrm{Co}^{2+}$ leached from the cobalt-based nanoparticles.

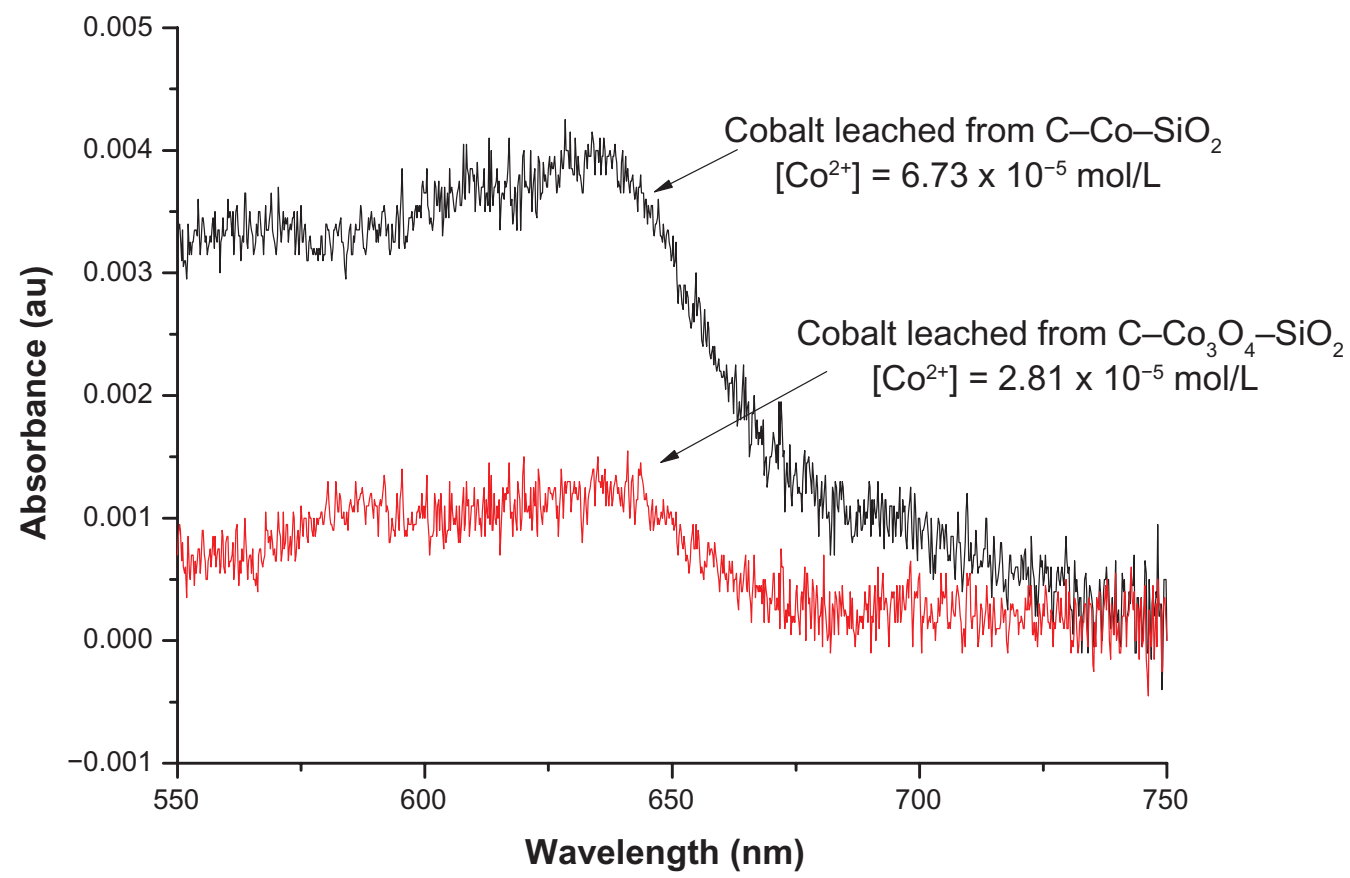

Figure $\mathbf{S} 8$ Ultraviolet-visible spectra of solutions collected after treatment with $\mathrm{C}-\mathrm{Co}-\mathrm{SiO}_{2}$ and $\mathrm{C}-\mathrm{Co}_{3} \mathrm{O}_{4}-\mathrm{SiO}_{2}$ nanoparticles and the respective concentration of the $\mathrm{Co}{ }^{2+}$ detected in the solutions. 
$\mathrm{SiO}_{2}$ nanoparticles) was about 2.4 times higher than that from the sample containing cobalt oxide (ie, $\mathrm{C}-\mathrm{Co}_{3} \mathrm{O}_{4}-\mathrm{SiO}_{2}$ nanoparticles). The higher amount of $\mathrm{Co}^{2+}$ released from the former may also be the reason behind the higher toxicity of $\mathrm{C}-\mathrm{Co}-\mathrm{SiO}_{2}$ nanoparticles compared with $\mathrm{C}-\mathrm{Co}_{3} \mathrm{O}_{4}-\mathrm{SiO}_{2}$ nanoparticles, and conversely for the $\mathrm{Co}_{3} \mathrm{O}_{4}$ phase to be more desirable for biological applications.

\section{References}

1. Young RS, Hall AJ. Ind Eng Chem Anal Ed. 1946;18:264-266.

2. Putsche HM, Malooly WF. Anal Chem. 1947;19:236-238.

3. Ronchese AD, Mermod M. C R Hebd Seances Acad Sci. 1959;249: $2421-2422$.

\section{Publish your work in this journal}

The International Journal of Nanomedicine is an international, peerreviewed journal focusing on the application of nanotechnology in diagnostics, therapeutics, and drug delivery systems throughout the biomedical field. This journal is indexed on PubMed Central, MedLine, CAS, SciSearch ${ }^{\circledR}$, Current Contents ${ }^{\circledR} /$ Clinical Medicine,
Journal Citation Reports/Science Edition, EMBase, Scopus and the Elsevier Bibliographic databases. The manuscript management system is completely online and includes a very quick and fair peer-review system, which is all easy to use. Visit http://www.dovepress.com/ testimonials.php to read real quotes from published authors. 